\title{
MICROCRACK TECHNOLOGY
}

Progress Report

for Period 1 October 1978 - 31 March 1979

\author{
Gene Simmons \\ Michael L. Batzle \\ and \\ Steven Shirey
}

Department of Earth and Planetary Sciences Massachusetts Institute of Technology Cambridge, Massachusetts 02139

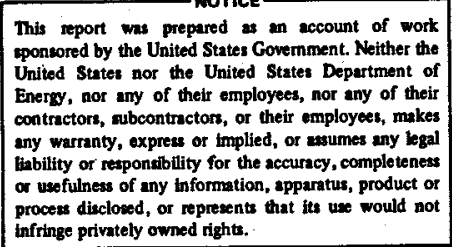

April 1979

Prepared for

The Department of Energy

under Contract No. ER-78-S-02-4972 


\section{DISCLAIMER}

This report was prepared as an account of work sponsored by an agency of the United States Government. Neither the United States Government nor any agency Thereof, nor any of their employees, makes any warranty, express or implied, or assumes any legal liability or responsibility for the accuracy, completeness, or usefulness of any information, apparatus, product, or process disclosed, or represents that its use would not infringe privately owned rights. Reference herein to any specific commercial product, process, or service by trade name, trademark, manufacturer, or otherwise does not necessarily constitute or imply its endorsement, recommendation, or favoring by the United States Government or any agency thereof. The views and opinions of authors expressed herein do not necessarily state or reflect those of the United States Government or any agency thereof. 


\section{DISCLAIMER}

Portions of this document may be illegible in electronic image products. Images are produced from the best available original document. 
TABLE OF CONTENTS

Title page

1

Table of contents 2

1.0 What we have done ( 1 October 78-31 March 79) 3

1.1 Introduction 3

1.2 Coso and Raft River samples 3

1.2.1 Locations 3

1.2.2 Unique characteristics of microcracks from
geothermal areas

1.3 Physical properties - hydraulic permeability and
electrical conductivity

1.3.1 Measurements 25

1.3 .2 Models 31

1.3.3 A future application: waste isolation $\quad 37$

1.4 Collection of samples 37

$\begin{array}{ll}2.0 \text { References } & 39\end{array}$ 
1.0 WHAT WE HAVE DONE ( 1 OCTOBER 78-31 MARCH 79)

A. Examined the microcracks in core samples from Coso and Raft River Geothermal Areas.

B. Discovered a set of observable characteristics of microcracks in rocks from geothermal regions that appears to be unique and to have considerable potential for exploration for geothermal regions.

c. Measured both permeability and electrical conductivity for a suite of samples with a range of microcrack characteristics. (We are using the data to develop general relationships.)

D. Collected a partial set of samples to study migration of radioactive elements.

1.1 Introduction

This study of microfractures in rocks from geothermal areas began in October 1978 and had the benefit of a previous study which had been supported by NSF. The techniques that we use, as well as other applications, are described in the publications Iisted in Table 1.

During the current period (1 October 1978-31 March 1979), we examined in detail samples from two geothermal areas, measured physical properties on a suite of samples, and collected several samples for study during the next contract year.

1.2 Coso and Raft River Samples

\subsubsection{Locations}

We have added specimens to the suites of samples already in hand from the Raft River, Idaho and Coso, California geothermal areas. They consist of cores from the Raft River Geothermal Injection Wells \#4 and \#6 and outcrop samples of cataclastic rocks from a fault zone at coso Hot springs. The locations of these new specimens are shown in Figures 1,2 , and 3 . We have 
Table 1

Manuscripts on Microcracks

\begin{tabular}{|c|c|c|c|}
\hline Authors & Title & Year & Where Published \\
\hline $\begin{array}{l}\text { Simmons, siegfried, } \\
\text { and Feves }\end{array}$ & $\begin{array}{l}\text { Differential'strain analysis: a } \\
\text { new method for examining cracks } \\
\text { in rocks }\end{array}$ & 1974 & $\begin{array}{l}\text { Journal of Geophysical } \\
\text { Research, } 79,4383-4385\end{array}$ \\
\hline $\begin{array}{l}\text { Simmons, Todd, and } \\
\text { Baldridge }\end{array}$ & $\begin{array}{l}\text { Toward a quantitative relation- } \\
\text { ship between elastic properties } \\
\text { and cracks in low porosity rocks }\end{array}$ & 1975 & $\begin{array}{l}\text { American Journal of } \\
\text { Science, 275, } 318-345\end{array}$ \\
\hline $\begin{array}{l}\text { Simmons, siegfried, } \\
\text { and Richter }\end{array}$ & $\begin{array}{l}\text { Characteristics of microcracks in } \\
\text { lunar rocks }\end{array}$ & 1975 & $\begin{array}{l}\text { Proceedings sixth Lunar } \\
\text { Science Conference, } \underline{3} \\
3227-3254\end{array}$ \\
\hline Batzle and Simmons & $\begin{array}{l}\text { Microfractures in rocks from two } \\
\text { geothermal areas }\end{array}$ & 1976 & $\begin{array}{l}\text { Earth and Planetary Sci- } \\
\text { ence Letters, 30, 71-93. }\end{array}$ \\
\hline Simmons and Richter & Microcracks in rocks & 1976 & $\begin{array}{l}\text { The physics } \\
\frac{\text { of }}{\text { Wi }} \frac{\text { Minerals }}{\text { ey-Intersiend }} \frac{\text { Chemistry }}{\text { andiecks. }} \\
105-137 .\end{array}$ \\
\hline Feves and Simmons & $\begin{array}{l}\text { Effects of stress on cracks in } \\
\text { Westerly granite }\end{array}$ & 1976 & $\begin{array}{l}\text { Bulletin of the Seismo- } \\
\text { logical society of Amer- } \\
\text { ica, } 66,1755-1765 \text {. }\end{array}$ \\
\hline $\begin{array}{l}\text { Richter, Simmons, } \\
\text { and siegfried }\end{array}$ & $\begin{array}{l}\text { Microcracks, micropores, and } \\
\text { their petrological interpretation } \\
\text { for } 72415 \text { and } 15418\end{array}$ & 1976 & $\begin{array}{l}\text { Proceedings Seventh } \\
\text { Lunar Science Conference, } \\
\text { 2. } 1901-1923 .\end{array}$ \\
\hline Simmons and Cooper & $\begin{array}{l}\text { DSA of the microcracks in GT-2 } \\
\text { core: interpretation and impli- } \\
\text { cations }\end{array}$ & 1976 & $\begin{array}{l}\text { Final Technical Report: } \\
\text { Los Alamos Scientific } \\
\text { Laboratory }\end{array}$ \\
\hline
\end{tabular}


Table 1 (continued).

\begin{tabular}{|c|c|c|c|}
\hline Authors & Title & Year & Where Published \\
\hline $\begin{array}{l}\text { Richter and } \\
\text { Simmons }\end{array}$ & $\begin{array}{l}\text { Microscopic tubes in igneous } \\
\text { rocks }\end{array}$ & 1977 & $\begin{array}{l}\text { Earth and Planetary } \\
\text { Science Letters, } 34 \\
1-12\end{array}$ \\
\hline Batzle and Simmons & $\begin{array}{l}\text { Assessing geothermal areas } \\
\text { during drilling }\end{array}$ & 1977 & $\begin{array}{l}\text { Geothermal: } \frac{\text { state of }}{\text { the Art, Trans Geother- }} \\
\text { mal Resources Council } \\
\text { Annual Meeting, 13-15. }\end{array}$ \\
\hline Batzle and simmons & $\begin{array}{l}\text { Geothermal systems: rocks, fluids, } \\
\text { fractures }\end{array}$ & 1977 & 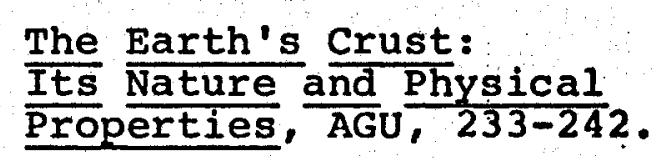 \\
\hline $\begin{array}{l}\text { Feves, simmons, } \\
\text { and siegfried }\end{array}$ & $\begin{array}{l}\text { Microcracks in crustal igneous } \\
\text { rocks: physical properties }\end{array}$ & 1977 & $\begin{array}{l}\text { The Earth's } \frac{\text { Crust: }}{\text { Its }} \text { Nature and } \frac{\text { Physical }}{\text { Properties }}, \frac{\text { AGU }}{95-117}\end{array}$ \\
\hline $\begin{array}{l}\text { Richter and } \\
\text { Simmons }\end{array}$ & $\begin{array}{l}\text { Microcracks in crustal igneous } \\
\text { rocks: microscopy }\end{array}$ & 1977 & $\begin{array}{l}\text { The Earth's } \frac{\text { Crust: }}{\text { Its }} \frac{\text { Nature }}{\text { Properties }}, \frac{\text { and }}{\text { AGU }} \frac{\text { Physal }}{149-180} \text {. }\end{array}$ \\
\hline Simmons and Cooper & $\begin{array}{l}\text { DSA of the microcracks in more } \\
\text { GT-2 core: interpretation and } \\
\text { implications }\end{array}$ & 1977 & $\begin{array}{l}\text { Final Technical Report: } \\
\text { Los Alamos Scientific } \\
\text { Laboratory. }\end{array}$ \\
\hline Batzle and simmons & $\begin{array}{l}\text { Fracturing and sealing in geo- } \\
\text { thermal systems }\end{array}$ & 1978 & $\begin{array}{l}\text { Proceedings volume, NSF- } \\
\text { RANN Geothermal Confer- } \\
\text { ence, } 1976, \text { submitted. }\end{array}$ \\
\hline $\begin{array}{l}\text { Siegfried and } \\
\text { Simmons }\end{array}$ & $\begin{array}{l}\text { Characterization of oriented } \\
\text { cracks with differential strain } \\
\text { analysis }\end{array}$ & 1978 & $\begin{array}{l}\text { Journai of Geophysical } \\
\text { Research, 83, 1269-1278. }\end{array}$ \\
\hline
\end{tabular}


Table 1 (continued).

\begin{tabular}{|c|c|c|c|}
\hline Authors & Title & Year & Where Published \\
\hline Simmons and Cooper & $\begin{array}{l}\text { Thermal cycling cracks in three } \\
\text { igneous rocks }\end{array}$ & 1978 & $\begin{array}{l}\text { International Journal of } \\
\text { Rock Mechanics and Mining } \\
\text { Science, } 15,145-148 .\end{array}$ \\
\hline $\begin{array}{l}\text { Siegfried, simmons, } \\
\text { Richter, and Horz }\end{array}$ & $\begin{array}{l}\text { Microfractures produced by a } \\
\text { laboratory scale hypervelocity } \\
\text { impact into granite }\end{array}$ & 1977 & $\begin{array}{l}\text { Proceedings Eighth Lunar } \\
\text { Science Conference, } 1 \text {. } \\
1249-1270\end{array}$ \\
\hline Cooper and Simmons & $\begin{array}{l}\text { The effect of cracks on the ther- } \\
\text { mal expansion of rocks }\end{array}$ & 1977 & $\begin{array}{l}\text { Earth and Planetary Sci- } \\
\text { ence Letters, } 36,404- \\
412 \text {. }\end{array}$ \\
\hline Wang and Simmons & $\begin{array}{l}\text { Microcracks in crystalline rock } \\
\text { from } 5.3-\mathrm{km} \text { depth in the Michigan } \\
\text { Basin }\end{array}$ & 1978 & $\begin{array}{l}\text { Journal of Geophysical } \\
\text { Research, } 83,5849-5856\end{array}$ \\
\hline Fehler and Simmons & $\begin{array}{l}\text { Effects of depth on microcracks in } \\
\text { granitic rock from Casco, Maine }\end{array}$ & 1979 & in preparation. \\
\hline $\begin{array}{l}\text { Siegfried, McQueen, } \\
\text { and Simmons }\end{array}$ & $\begin{array}{l}\text { Shock-induced microfractures in } \\
\text { six terrestrial igneous rocks } \\
\text { characterized with differential } \\
\text { strain analysis }\end{array}$ & 1978 & $\begin{array}{l}\text { Journal of Geophysical } \\
\text { Research, submitted. }\end{array}$ \\
\hline $\begin{array}{l}\text { Siegfried, Simmons, } \\
\text { McQueen, and Horz }\end{array}$ & $\begin{array}{l}\text { Are the microcracks in lunar } \\
\text { samples representative of those } \\
\text { in situ in the lunar crust? }\end{array}$ & 1979 & in preparation. \\
\hline $\begin{array}{l}\text { Padovani, Batzle, } \\
\text { and Simmons }\end{array}$ & $\begin{array}{l}\text { Characteristics of microcracks } \\
\text { in samples from the drill hole } \\
\text { Nordlingen } 1973 \text { in the Ries } \\
\text { Crater, Germany }\end{array}$ & 1979 & $\begin{array}{l}\text { Proceedings Ninth Lunar } \\
\text { Science Conference, } \\
\text { in press. }\end{array}$ \\
\hline
\end{tabular}


Table 1 (continued).

\begin{tabular}{|c|c|c|c|}
\hline Authors & Title & Year & Where Published \\
\hline $\begin{array}{l}\text { Simmons, Batzle, and } \\
\text { Cooper }\end{array}$ & $\begin{array}{l}\text { The characteristics of micro- } \\
\text { cracks in several igneous rocks } \\
\text { from the chalk River site: a } \\
\text { preliminary report }\end{array}$ & 1978 & $\begin{array}{l}\text { Department of Energy, } \\
\text { Mines, and Resources, } \\
\text { Canada. }\end{array}$ \\
\hline $\begin{array}{l}\text { Hall, Miller, and } \\
\text { Simmons }\end{array}$ & $\begin{array}{l}\text { A technique for the precise } \\
\text { measurement of acoustic velocity } \\
\text { in, and between, boreholes with } \\
\text { a sparker source }\end{array}$ & 1979 & $\begin{array}{l}\text { Geoexploration, sub- } \\
\text { mitted. }\end{array}$ \\
\hline Hall and Simmons & $\begin{array}{l}\text { Seismic velocities of Lewisian } \\
\text { metamorphic rocks at pressures } \\
\text { to } 8 \text { kbar: relationship to } \\
\text { crustal layering in } N \text {. Britain }\end{array}$ & 1979 & $\begin{array}{l}\text { Geophys J. Roy Astron. } \\
\text { Soc. I in press. }\end{array}$ \\
\hline
\end{tabular}




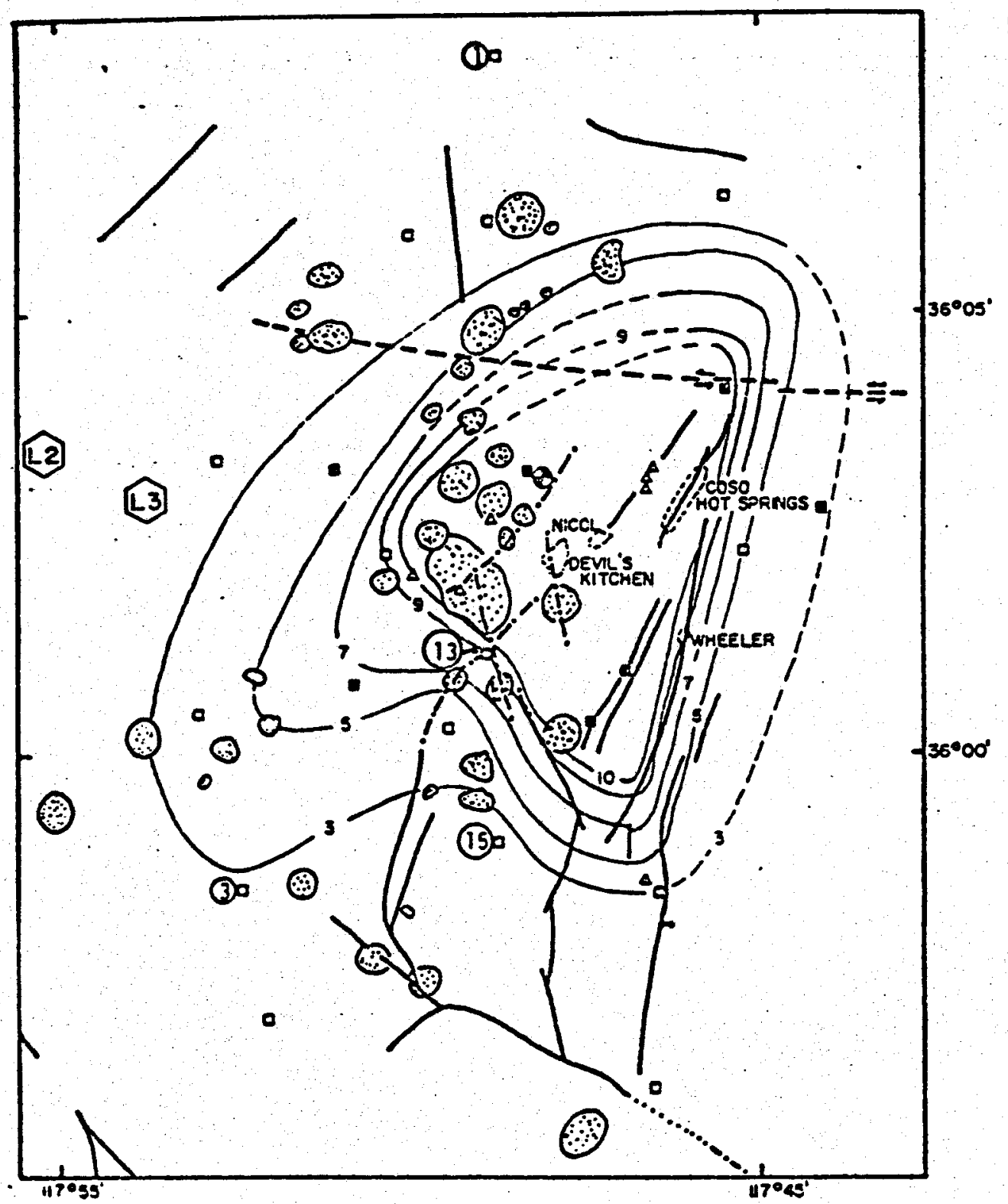

STRUCTURE \& HEAT FLOW MAP, COSO GEOTHERMAL AREA, CALIFORNIA
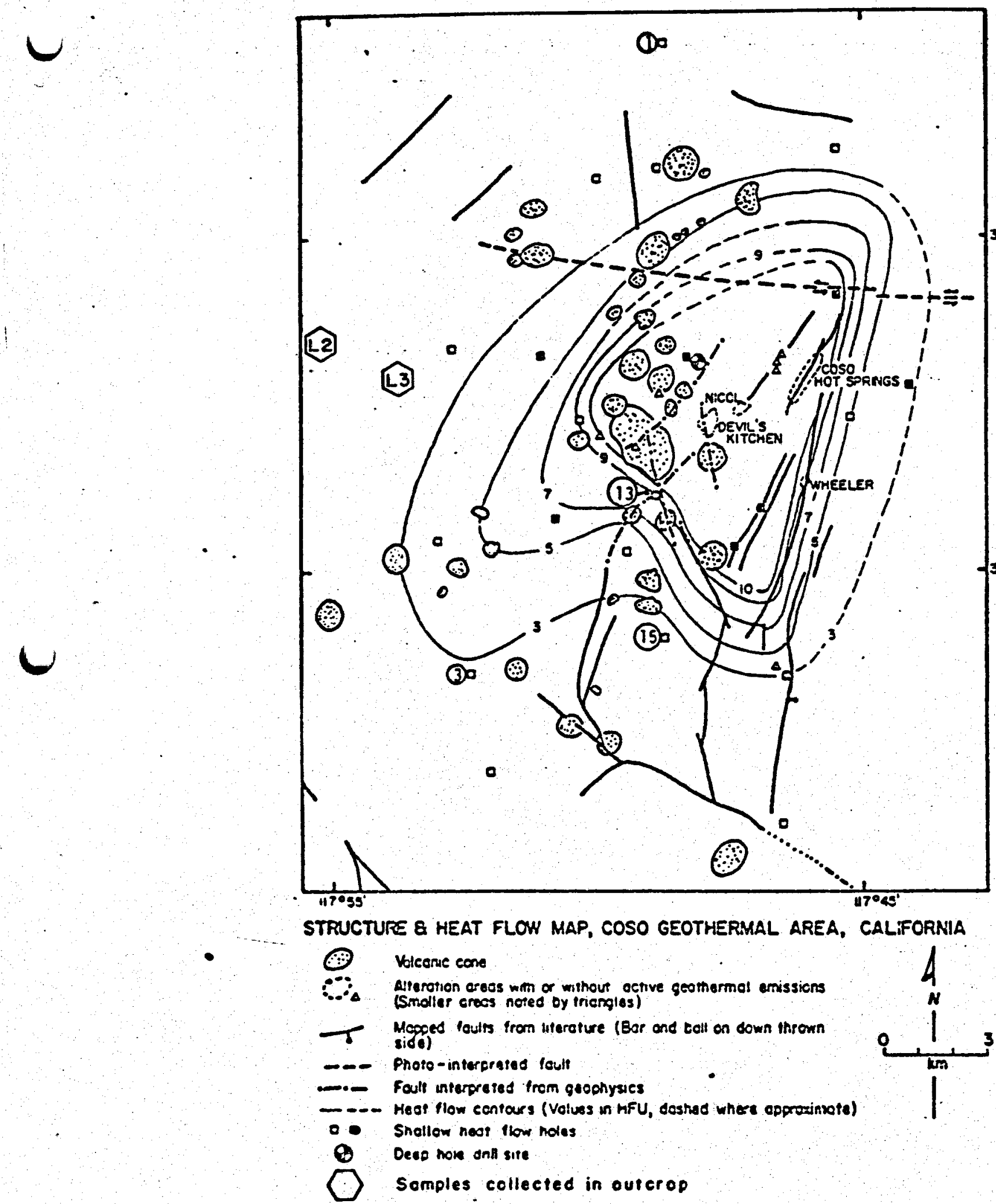

Figure 1. Structure and heat flow map, Coso geothermal area, California. Previous samples were obtained from the shallow holes identified by circled numbers and the deep hole drill site. New samples have been collected in outcrop at $L 2$ and L3. (After Combs, 1976; Furgerson, 1973; and Lanphere et al., 1975). 


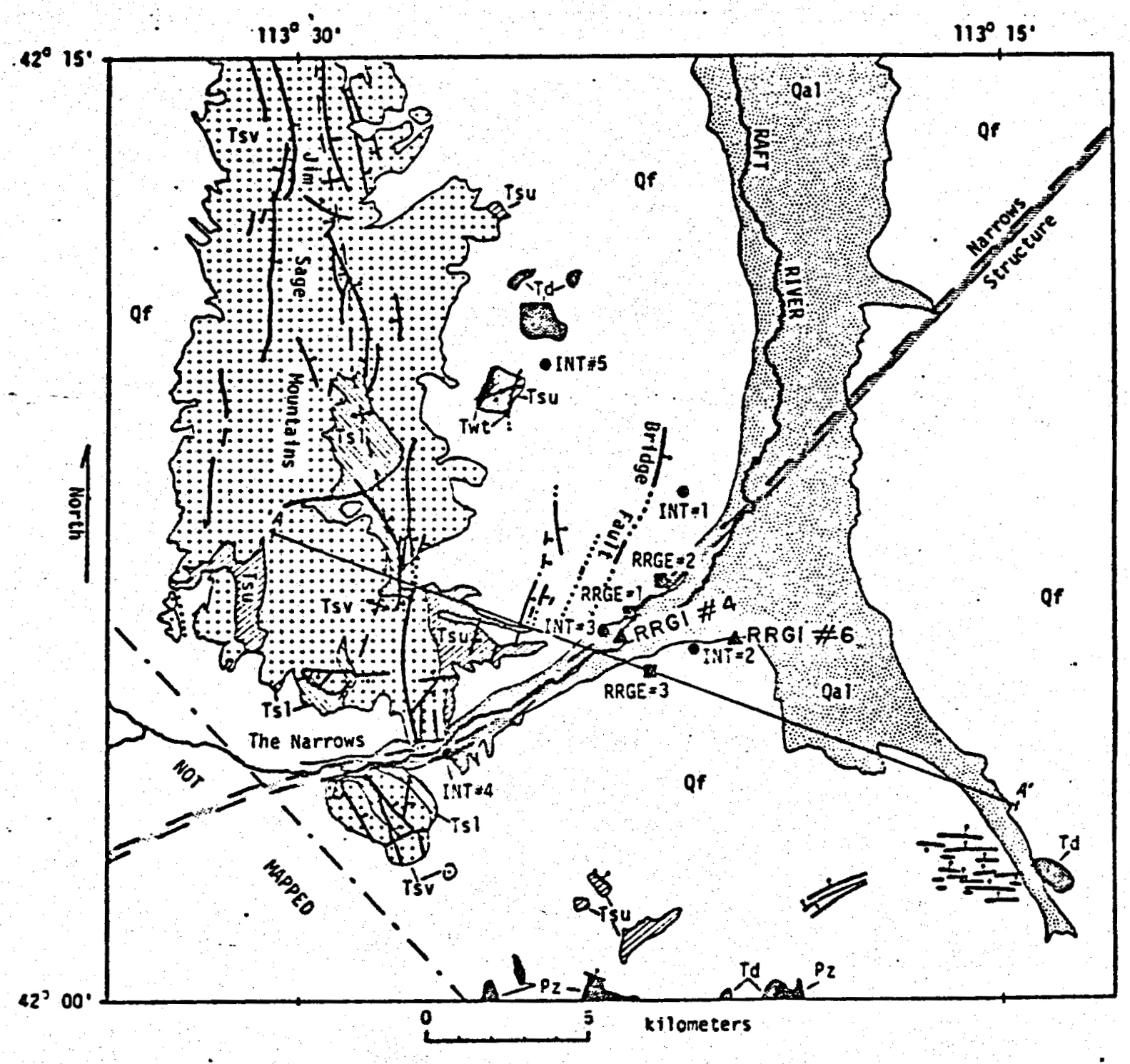

Figure 2. Geology, structure, and well locations for the Raft River area (after Villiams et al.. 1974 and Villiams et al., 1976). See Figure 3 for legend. New samples are from wells RRGI\#4 and RRGI\#6. 


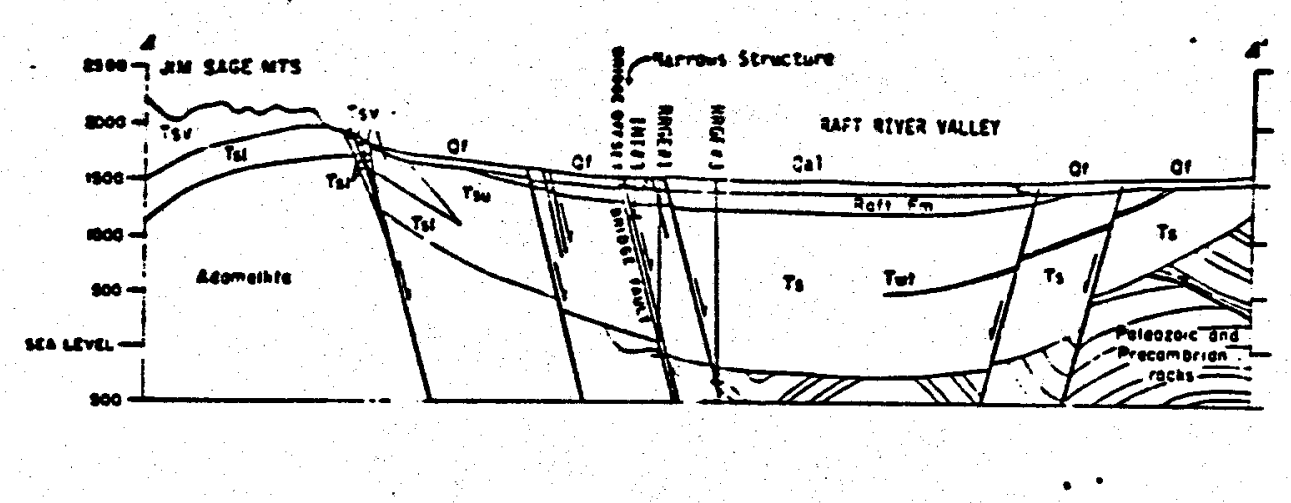

LEGEN D
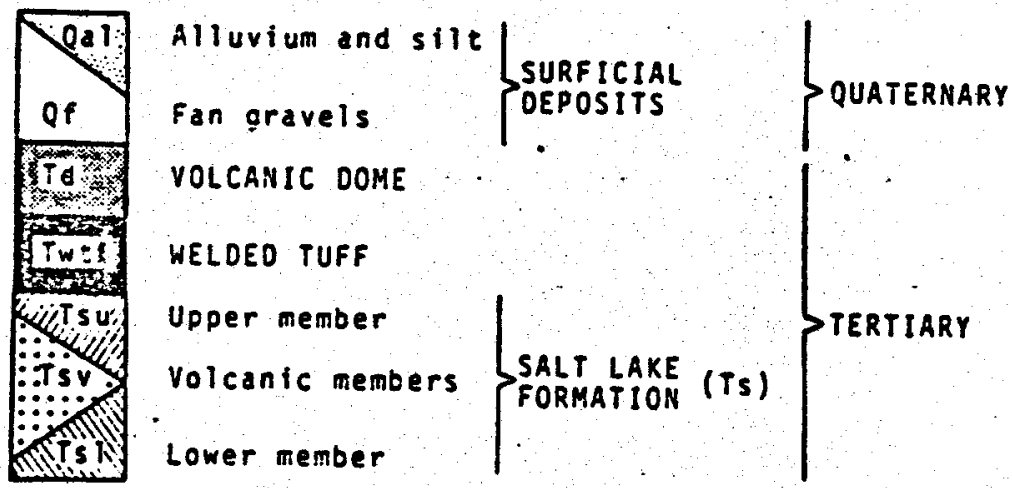

INCONFORMITY

VOLCANIC DOME

WELDED TUFF

Upper member

Volcanic members

Lower member

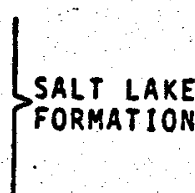

EN $(T s)$

PPALEOZOIC

\section{- MAP SYMBOLS.}

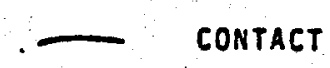

L. FaULT gar and ball on downthrown side.

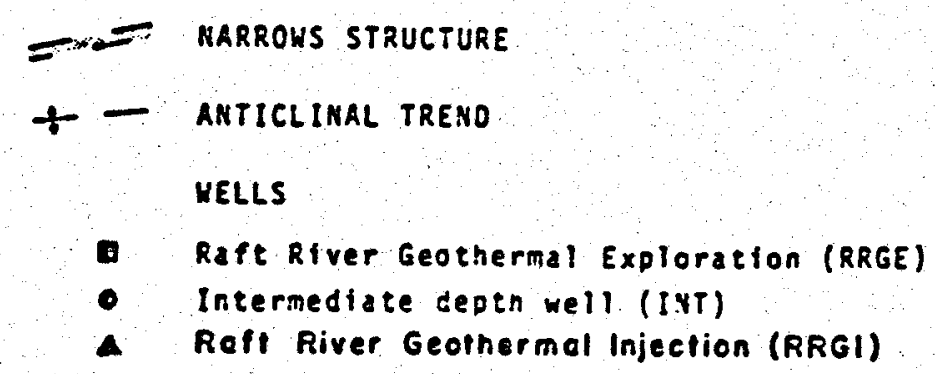

a Roft River Geothermal Injection (RRGI)

Figure 3. Cross-section of Raft River area from $A$ to $A$ ' (see Figure 2). Note closely-spaced normal faulting continues at depth. RRGE\# 1 and Int\# 3 are projected onto plane of crosssection. Same source as Figure 2 . 
also obtained downhole information from the Raft River area in the form of Compensated Densilog, BMC Acoustilog, Dual Induction Focused Log with Linear Correlation and Compensated Neutron Logs. 1.2.2 Unique Characteristics of Microcracks from Geothermal Areas

We have learned to recognize in the scanning electron microscope (SEM) a set of characteristic features of microcracks that appear to be unique and also typical for the host rocks of hydrothermal systems (Shirey et al., 1978). If the set continues to be unique after many more samples are examined, then it may prove to be a valuable guide in the exploration for geothermal systems. The set of characteristics consists of (A) bridges in microcracks, (B) modified crack walls, (C) repeated fracturing and sealing of the fractures, (D) existence of a critical crack width, and (E) dominance of transgranular cracks. We shall illustrate our discussion of these features with examples observed in a specimen from coso.

A. Bridges. Microcracks in rocks from geothermal systems usually have bridging structures that span the distance between the walls on either side of an open microcrack (Figure 4). The presence of bridges is unequivocal evidence that the cracks were open in situ and have not been disturbed during collection or preparation of the specimen. Modification of bridges by cracking during pull-apart or by crumpling during squeezing provides a calibration for changes in crack width. The presence of bridges is an indication that the mechanical closing of a microcrack will be incomplete in the laboratory; some porosity will remain along the microcrack plane even when the microcrack is closed mechánically.

B. Modified Crack Walls. Recent, fresh, open microcracks 


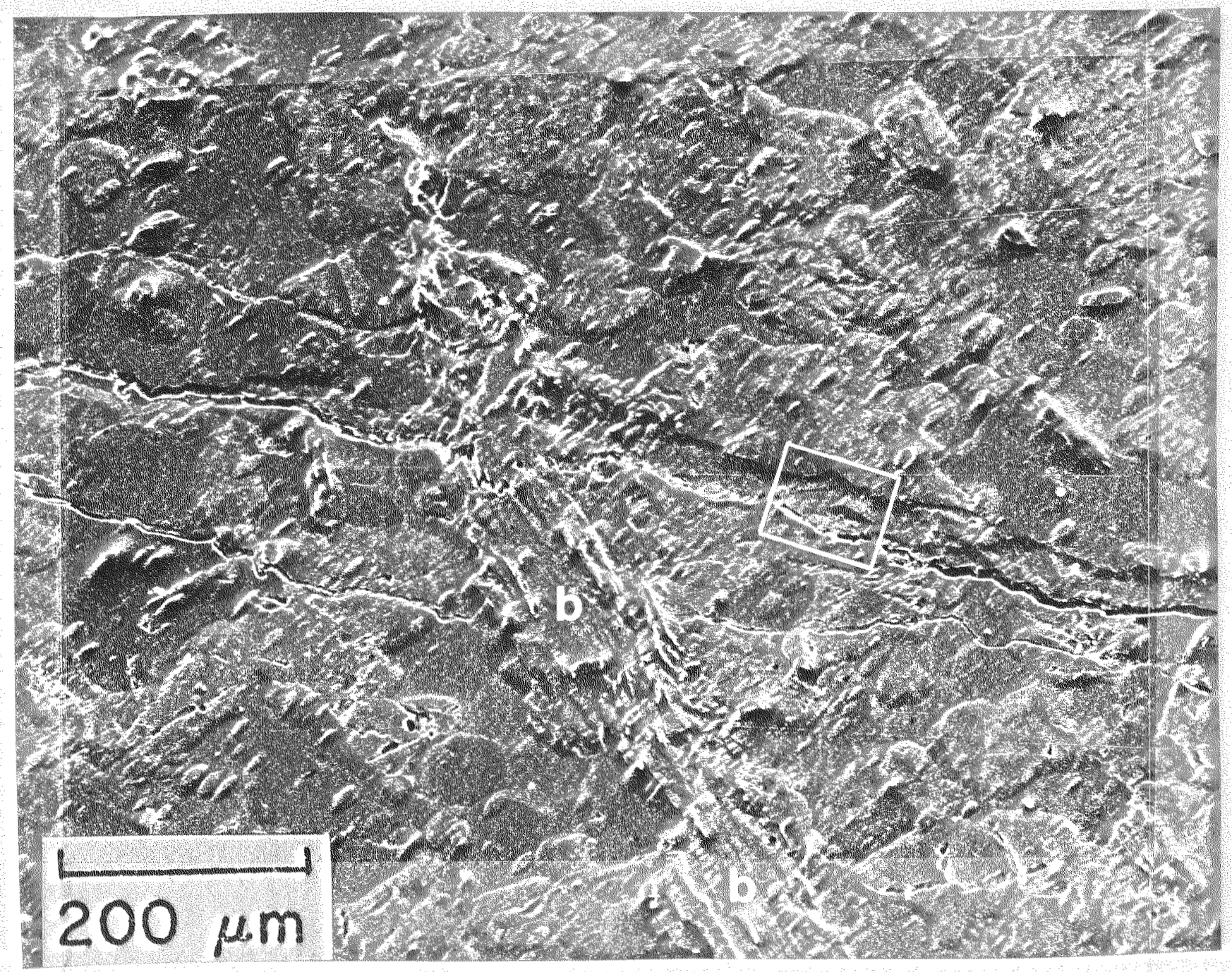

Figure 4. Coso sample 1650-1033. The branching system of transgranular cracks (TGC) in center cuts across composite biotite grain (b). TGC is intermittently sealed. Area in box is shown in Figure 5. SEM micrograph, secondary electron image. 
such as those produced by shock or unconfined shear stress (thin section making) have walls that appear to be matched perfectly across the microcrack open space. We argue that these fresh surfaces do not last long in contact with hot circulating fluids. Microcracks in rocks from geothermal areas have walls that have been modified from their original, fresh appearance. Evidence for modification consists of mismatched walls and textural relief on the surface of the wall itself. Figures 5 and 6 show both features. Textural relief on the microcrack wall can be of positive or negative type. The positive type is an overgrowth; evidence of incipient crack-sealing by mineral precipitation. The negative type is an etch pit; a signal of incipient crack widening by chemical solution.

C. Repetition of Fracturing and Sealing. Microcracks in rocks from geothermal systems have been sites at which several successive episodes of cracking and sealing have occurred. Close examination of a typical sequence shown in Figures 4-6 reveals a microcrack history of : fracturing, sealing with calcite, refracturing, and modification of calcite-host wall by mineral precipitation. Megascopic models of typical geothermal systems include intermittent refracturing to sustain the connective pathways of the circulatory system. Refracturing offsets the tendency of the system to seal itself by rapid precipitation from saturated solutions. Repeated fracturing on the microscale indicates that dynamic processes essential to the viability of the geothermal system affect even small volumes of rock. Normal megascopic observations often overlook these same small volumes of rock and thus exclude them from the models of the geothermal circulation system.

D. Critical Crack Size. A dependence exists between the size of the microcrack in rocks from a geothermal area and the complexity of the textures developed in the microcrack. Cracks less than $30 \mu \mathrm{m}$ in width are usually sealed by a 


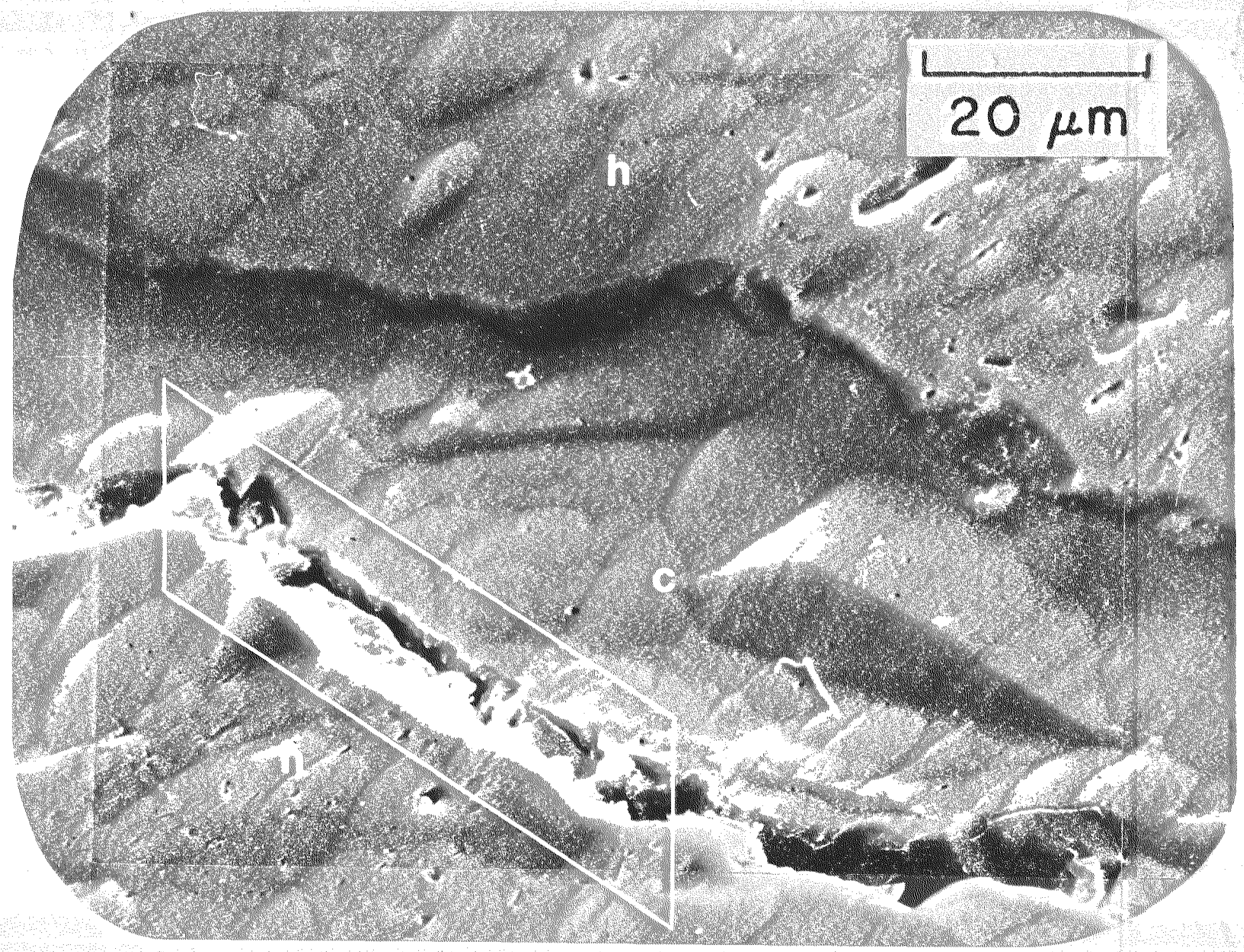

Figure 5. Coso sample 1650-1033, Enlargement of an area

in Figure 4. Calcite (c) seals most of volume of microcrack in porous host $(\mathrm{h})$. Refracturing formed partially open microcrack located at lower edge of calcite. The partially open microcrack contains new mineral growth. The area in box is show in Figure 6. SEM micrograph, secondary electron image. 


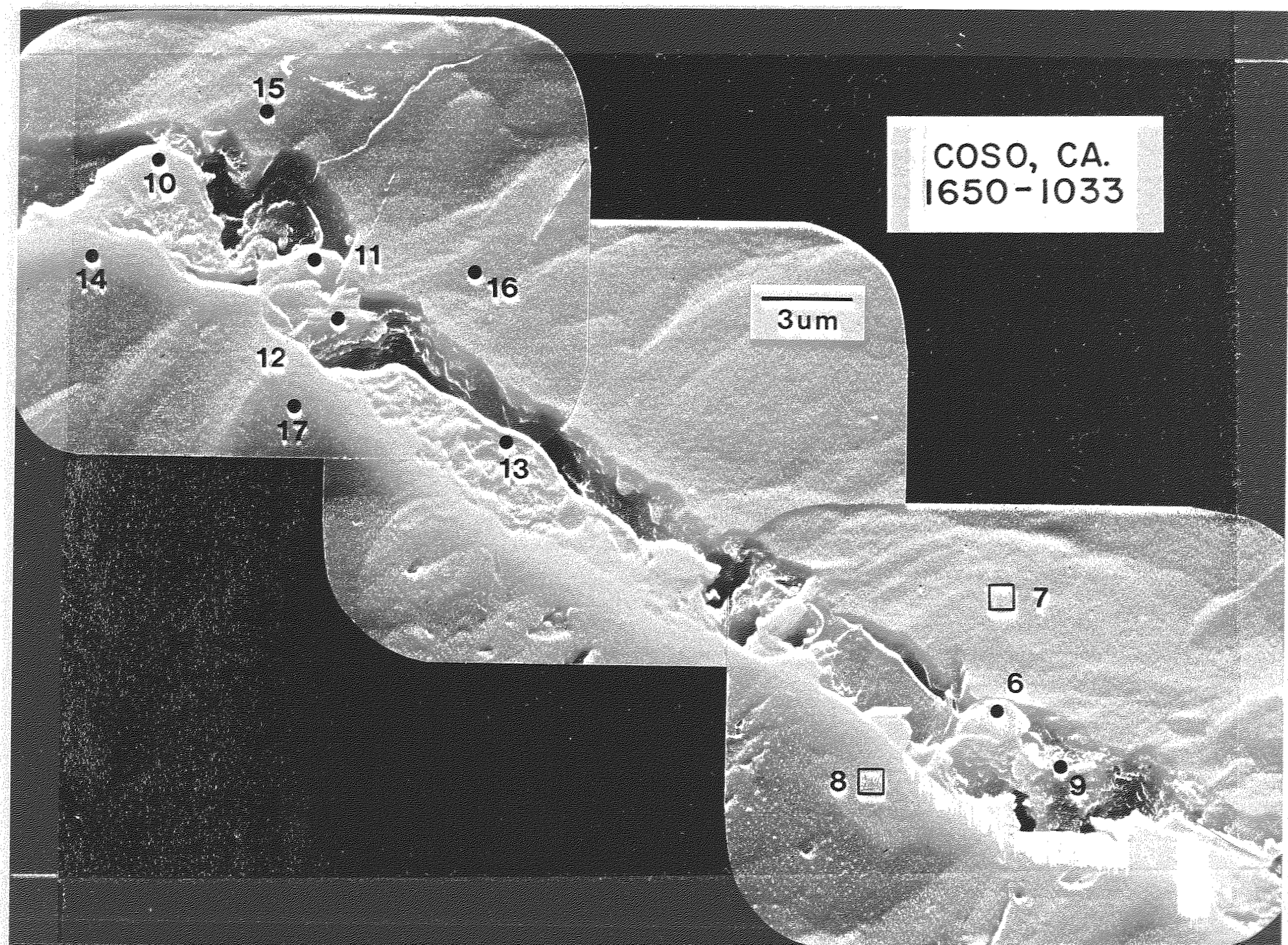

Figure 6. Coso sample 1650-1033. Enlargement of an area in Figure 5. Numbered spots are locations of energy-dispersive x-ray analyses (EDX). The partially open raicrocrack between calcite and host is partially spanned by incomplete bridges (see points 6,9 and 11, 12) and partially filled with new mineral growth (see points 10, 13). Notice bumpy texture of microcrack wall. SEM micrograph mosaic, secondary electron image. 
single episode of sealing and the composition of the sealing material approximates the composition of the host. Cracks greater than $100 \mu \mathrm{m}$ in width are usually sealed with several generations of phases whose composition often differs greatly from that of the host. The existence of this dependence implies that a critical microcrack width exists which is probably different for different fluids and host rocks. Microfractures thinner than the critical width have simple textures because they carry fluids whose equilibria are dominated by the microcrack host. Microcracks wider than the critical width have complex textures because they carry fluids whose equilibria are dominated by fluid chemistry. E. Dominance of Transgranular Cracks. Transgranular cracks (TGC) are the dominant microcrack type found in geothermal systems. This particular crack morphology is interpreted by us to be evidence against a mechanism of microcrack formation related to properties of individual constituent minerals such as differential thermal expansion or cleavage. The TGC morphology suggests a microfracture mechanism such as corrosion fracture, hydrofracture or tectonic stress fracture akin to the mechanism of fracture in the megascopic system.

All five characteristics of microcracks in geothermal rocks are seldom developed in a single crack-section. However, they are all present in suites of samples located close enough together to be within the volumetric confines of an active geothermal circulation system. The set of characteristics of microcracks in geothermal rocks is unique when compared with the characteristics of microcracks in rocks from non-hydrothermal regions that we have investigated: rhyolite, quartz-monzonite, gabbro, granite, diabase (Richter and Simmons, 1977); granulite and amphibolite (Padovani et al.,1979a); quartz arenite, orthoquartzite, arkose 
(Simmons, 1979); lunar dunite and lunar breccia (Richter et al.. 1976): lunar basalts (Simmons et al., 1975); shocked aplite, amphibolite and flasergneiss (Padovani et al., 1979b); and stressed granite (Feves and Simmons, 1976). We conclude that microcracks in geothermal rocks have a unique set of features that result from episodic stress buildup and the interaction of hot reactive fluids in the circulation system with the rocks.

Detailed examination of microcracks in a drill core sample from the Raft River Geothermal Injection Well \#6 at 3005' depth, provides a good example of the application of geothermal microfracture characteristics to the analysis of a small volume of rock. We know our sample has been collected proximal to the Raft River area. The central question is: Does the morphology of the microcrack allow us to connect this small parcel of rock to the geothermal circulation system? A firm answer to this question will help define the limits of the system. The capability to answer this question is necessary to construct an exploration tool for geothermal energy resources based on microcracks.

In hand specimen, the sample is a grey-green silty sandstone. In thin-section it is texturally immature with angular, poorly sorted quartz as the dominant detrital mineral and orthoclase, muscovite, biotite, chlorite, plagioclase, and apatite as detrital minerals of lesser abundance. Authigenic pyrite granules in aggregates shaped like cauliflowers are dispersed at random in the rock. The detrital minerals are supported by a matrix of microcrystalline material that contains spotty concentrations of calcite or microcrystalline silica. Analcime and calcite occur 
in a $2 \mathrm{~mm}$ wide microfault visible at one side of the section. The porous and microcrystalline-amorphous nature of the matrix is evident in the SEM images (Figure 7). At higher magnification (Figure 8 ), the matrix is seen to be a complex mass of relatively impermeable clay that changes to airy aggregates of discrete grains near detrital grain boundaries. Energy dispersive $x$-ray analyses indicate that the clay is near illite in composition, but contains some Ti. The microfault and analcime along it are readily visible at low magnifications on the SEM (Figure 9). However, of special interest for the assessment of the geothermal system, is a series of small cracks that parallel bedding and appear to be connected to the microfault. An SEM micrograph mosaic (Figure 10a) along the fracture at the center of Figure 9 reveals $100 \mu \mathrm{m}$ long open crack segments $\sim 10 \mu \mathrm{m}$ in width which provide considerable porosity along the bedding plane. Analcime similar in composition to the analcime near the microfault grows in patches along the bedding plane microcrack. Analcime bridges are well developed (Figures 10a and 10b) and span the microcrack without breaks at several spots. The microcrack thus displays an original in situ width that has remained unchanged through drilling, removal of the core to surface and sample preparation. However, the microcrack wall has been altered in width by fluids in situ and now has variations of at least 5 to $12 \mu \mathrm{m}$ along it (Figure 10a). The microcrack walls have been modified also by spiky analcime overgrowths into open fracture space (Figure 10b). Multiple sealing textures are absent; an observation consistent with the narrow width $(<20 \mu \mathrm{m})$ of the microcrack 


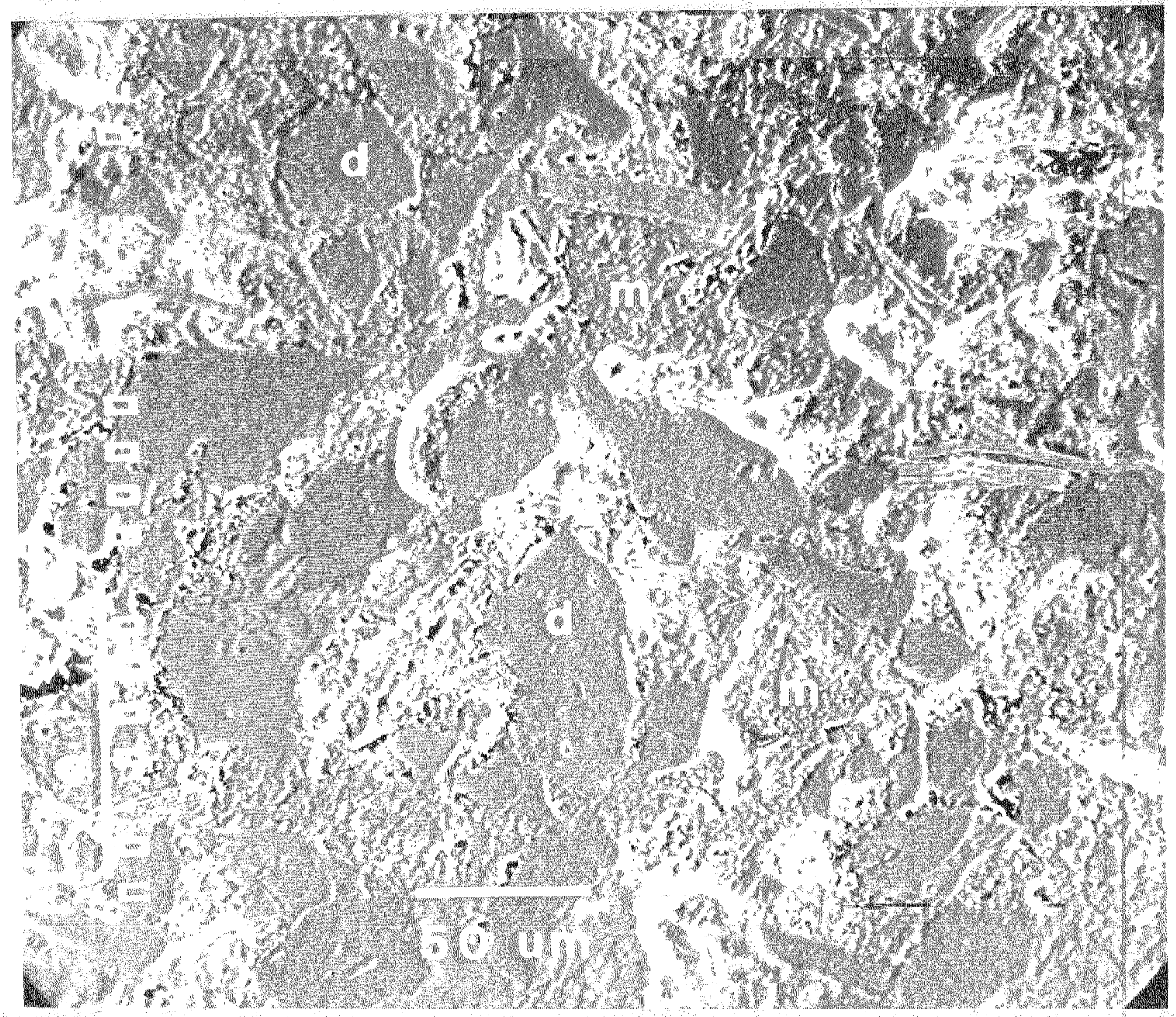

Figure 7. Silty sandstone from Raft River Geothermal Injection well $\# 6,3005^{\prime}$. Detrital grains (d) are smooth surfaced and matrix (m) is irregular porous material. Note areas of matrix separate most detrital grains. SEl micrograph, secondary electron image. 


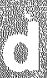

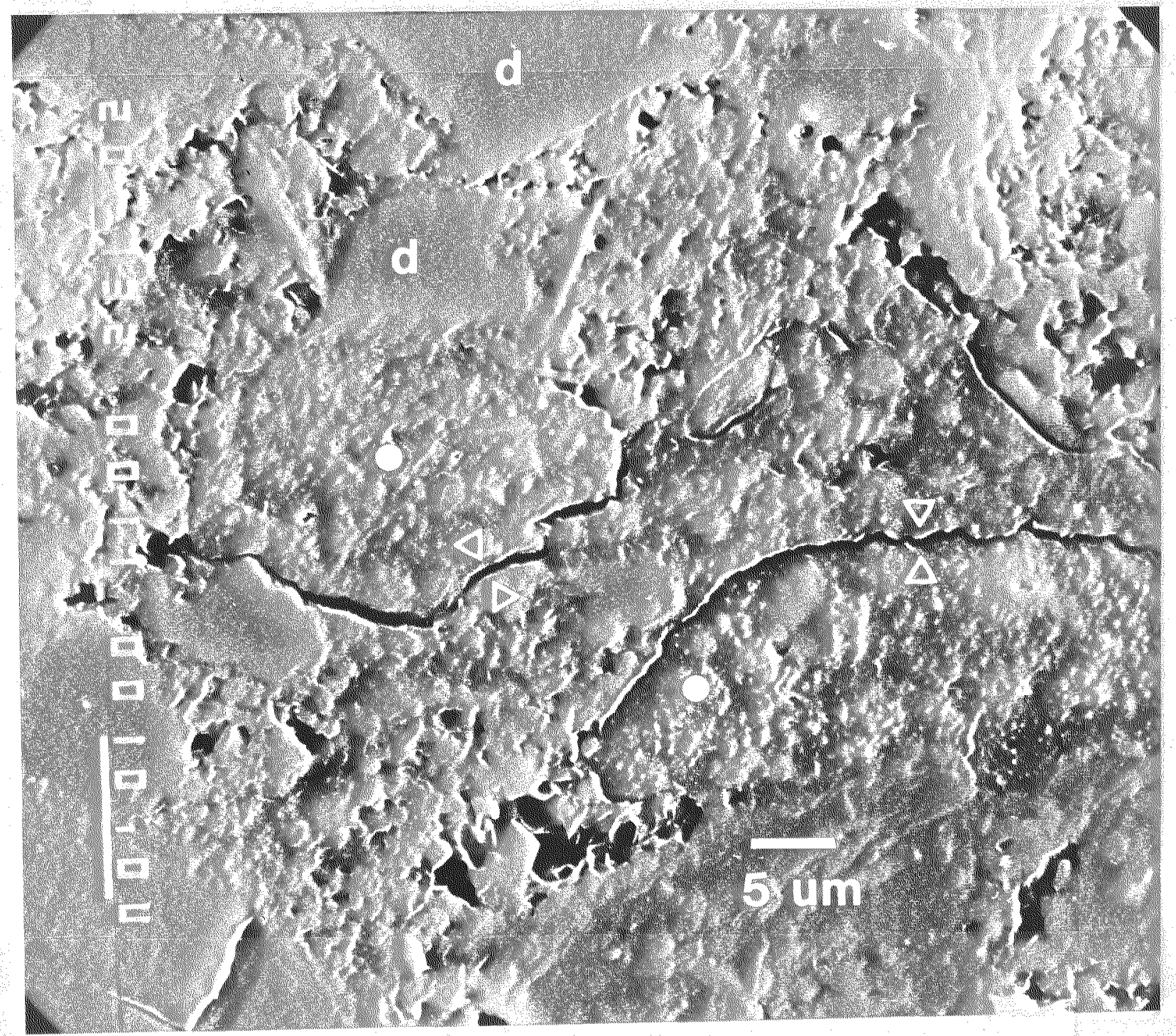

Figure 8. Detailed view of silty sandstone matrix from Raft River Geothermal Injection well \#6, $3005^{\prime}$. The compact
material in center is clay. Note the dessication cracks EDX analyses were taken at white circles. The matrix changes to airy aggregates of discrete grains near contact with some detrital materials (d). SEM micrograph, secondary electron image. 


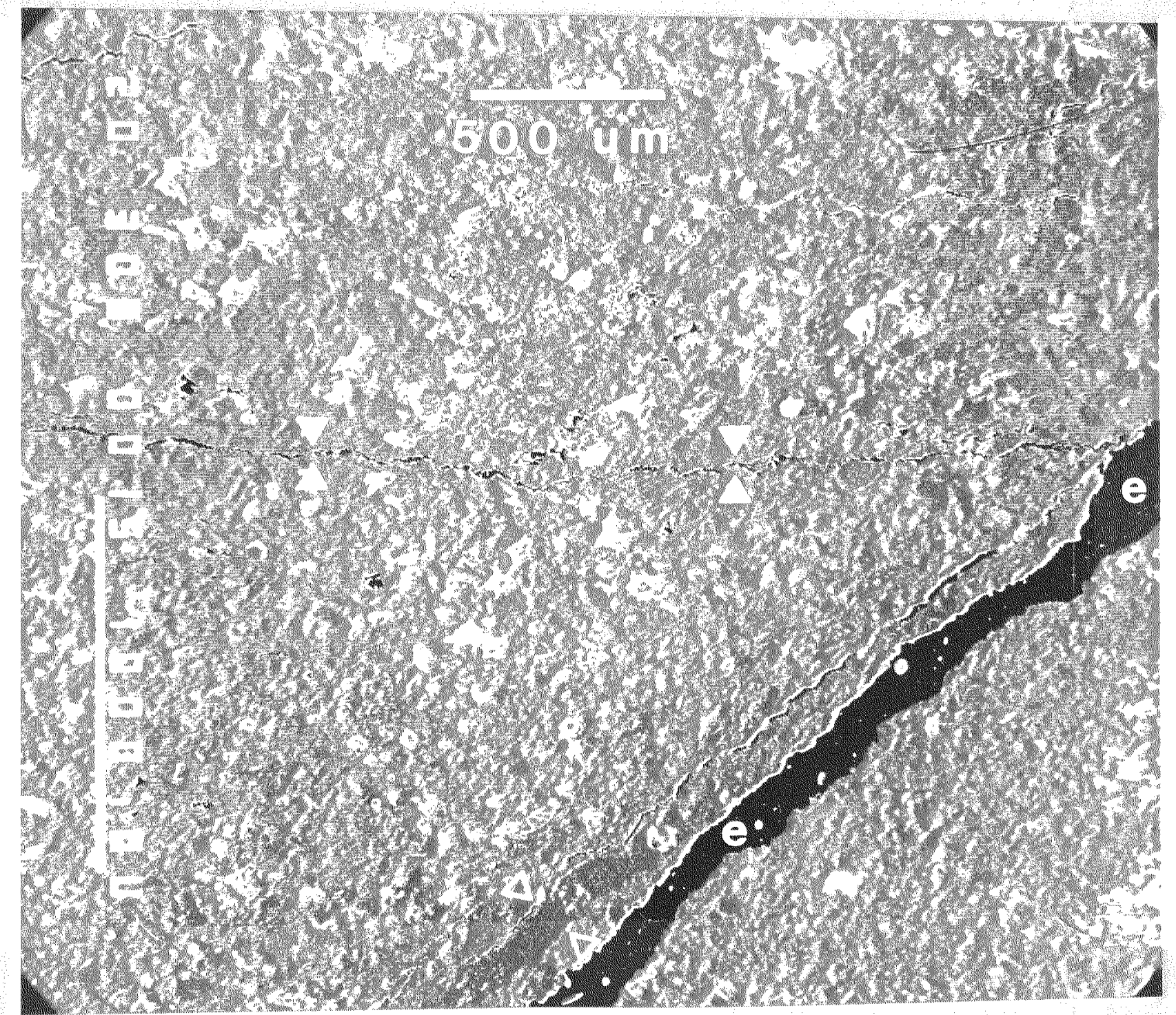

Figure 9. Silty sanastone from Raft River Geothermal Injection Weli \#6. Note epoxy-filied (e) microfault at lower right. Paraliel to it is an analcime-filled vein $(\nabla)$. smaller, bedaing-place fractures (1) are connected to microfault. SEM micrograph, secondary electron image. 


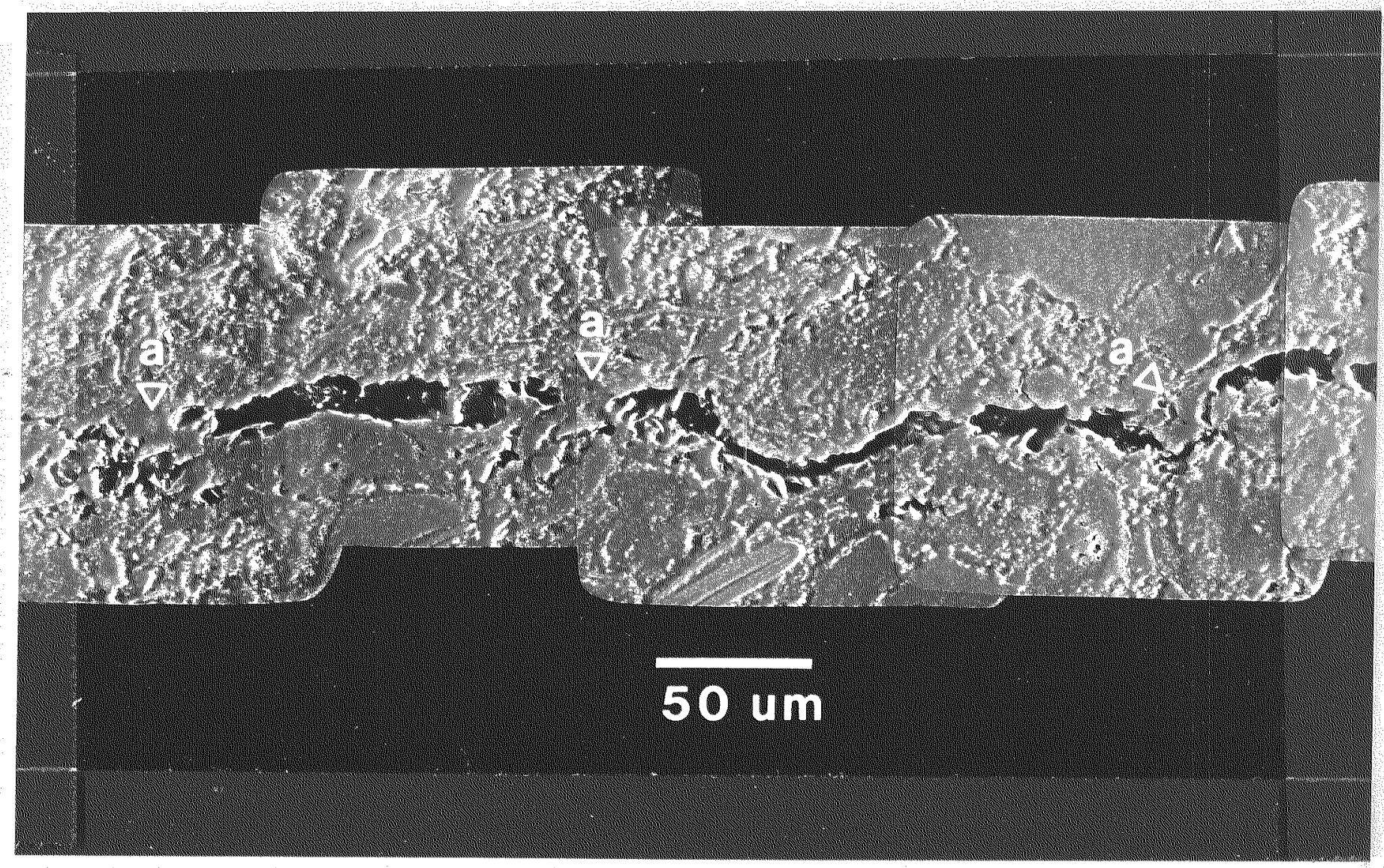

Figure 10a. Open bedaing-plane microcrack in silty sandstone. Note the supports provided by analcime bridges (a). 


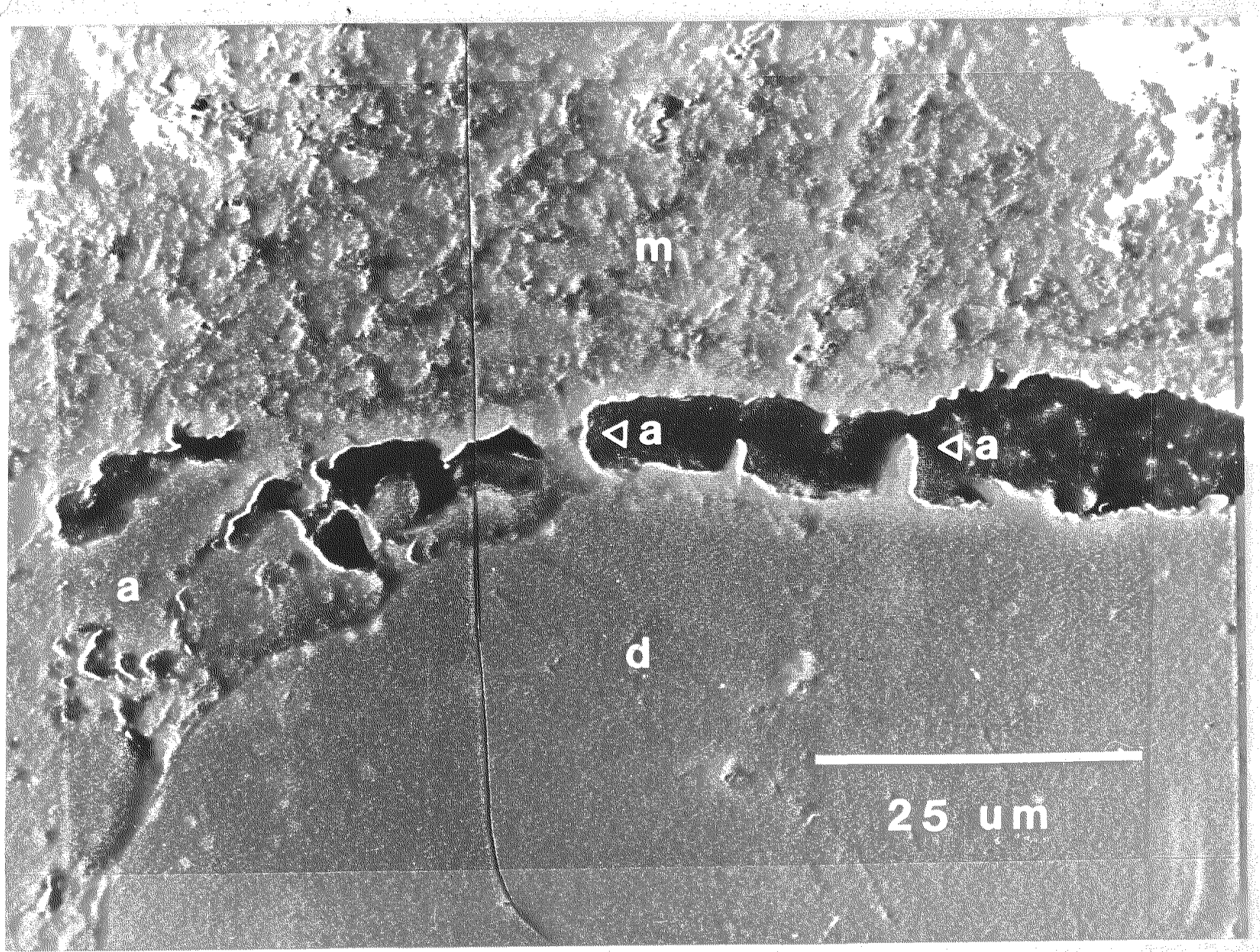

Figure 10b. Analcime (a) growths in open bedaing-plane microcrack. They form spikes, bridges, and irregular masses. Microcrack walls are located entirely in the detrital feldspar grain (d). Note that the wall near the illite-rich matrix (m) consists entirely of new mineral growth. Both $10 \mathrm{a}$ and $10 b$ are SEM micrograph mosaics, secondary electron image. 
and the previously observed size dependence of multiple sealing textures. The bedding plane microcrack is transgranular.

Four of the five textural characteristics typical of 'geothermal microcracks' are present in this one bedding plane microcrack, suggesting the microcrack was connected to the periphery of a hydrothermal circulation system. It is clear from textures along the bedding plane microcrack that analcime was the last phase to grow in equilibrium with fluid. The upper limit of analcime stability in $\mathrm{H}_{2} \mathrm{O}-\mathrm{rich}$ siliceous environments is defined by the reaction: Analcime + Quartz $\leftrightarrows$ Albite + Fluid (Liou, 1971). The sample was retrieved as drill core from a depth of $3005^{\prime}$ where the pressure would be approximately 90 to 270 bars. Over this pressure range, analcime can grow in equilibrium with fluid only at temperatures below $200^{\circ} \mathrm{C}$. This observation agrees with well-water temperatures of $150^{\circ} \mathrm{C}$ determined by $\mathrm{Na}-\mathrm{Ca}-\mathrm{K}$ geothermometry (Kunze et al., 1976; Williams et al., 1976) and measured downhole hot water temperatures of $147^{\circ} \mathrm{C}$ (Kunze et al., 1976; Stoker et al., 1976, 1977; and Kunze, 1977). We have specifically chosen a rock for this example whose relationship to the geothermal system is ambiguous after megascopic or standard petrographic examination. With the SEM, we have observed features in microcracks that indicate a physicalchemical connection between a small volume of rock and a geothermal circulation system. By using the SEM to image microcracks and by applying our microcrack characteristics as a set of criteria, we can test small volumes of unknown rock for participation in a hydrothermal circulation system. 
1.3 Physical Properties - Hydraulic Permeability and Electrical Conductivity

\subsubsection{Measurements}

Hydraulic permeability and electrical conductivity were measured as a function of confining pressure. Samples consisted of westerly granite, both virgin and preheated to 300 and $500^{\circ} \mathrm{C}$, and of Frederick diabase preheated to $700^{\circ} \mathrm{C}$. The samples were heated and cooled at rates of less than $1^{\circ} \mathrm{C}$ per minute to prevent spatial thermal gradient effects. Figure 11 shows the experimental set-up. The methods used were almost identical to those described in Chapter 3 of the RANN/ERDA final report. The only variation was that the fluid flowed from the sample to a container exposed to the atmosphere rather than to a low pressure reservoir. Conductivities were measured in similar experimental apparatus, but without input and outlet fluid ports. Conductivities and permeabilities were measured on separate samples. The technique is similar to that used by Brace et al. (1968). The results are shown in Figures $12,13,14$, and 15.

Consistent and significant variations can be observed in the curves going from virgin Westerly granite to preheated Frederick diabase. Virgin westerly granite is filled with natural fractures. The fracture walls, as observed with the SEM, are rough, pitted, and mismatched. Crack closure is largely incomplete even at high pressures. As the crack porosity increases due to heating (Figures 13 and 14 ), note the change not only in the shapes of the curves but also in the relative separation of conductivity and permeability as confining pressure increases. The cracks have changed from all natural in virgin granite to all 


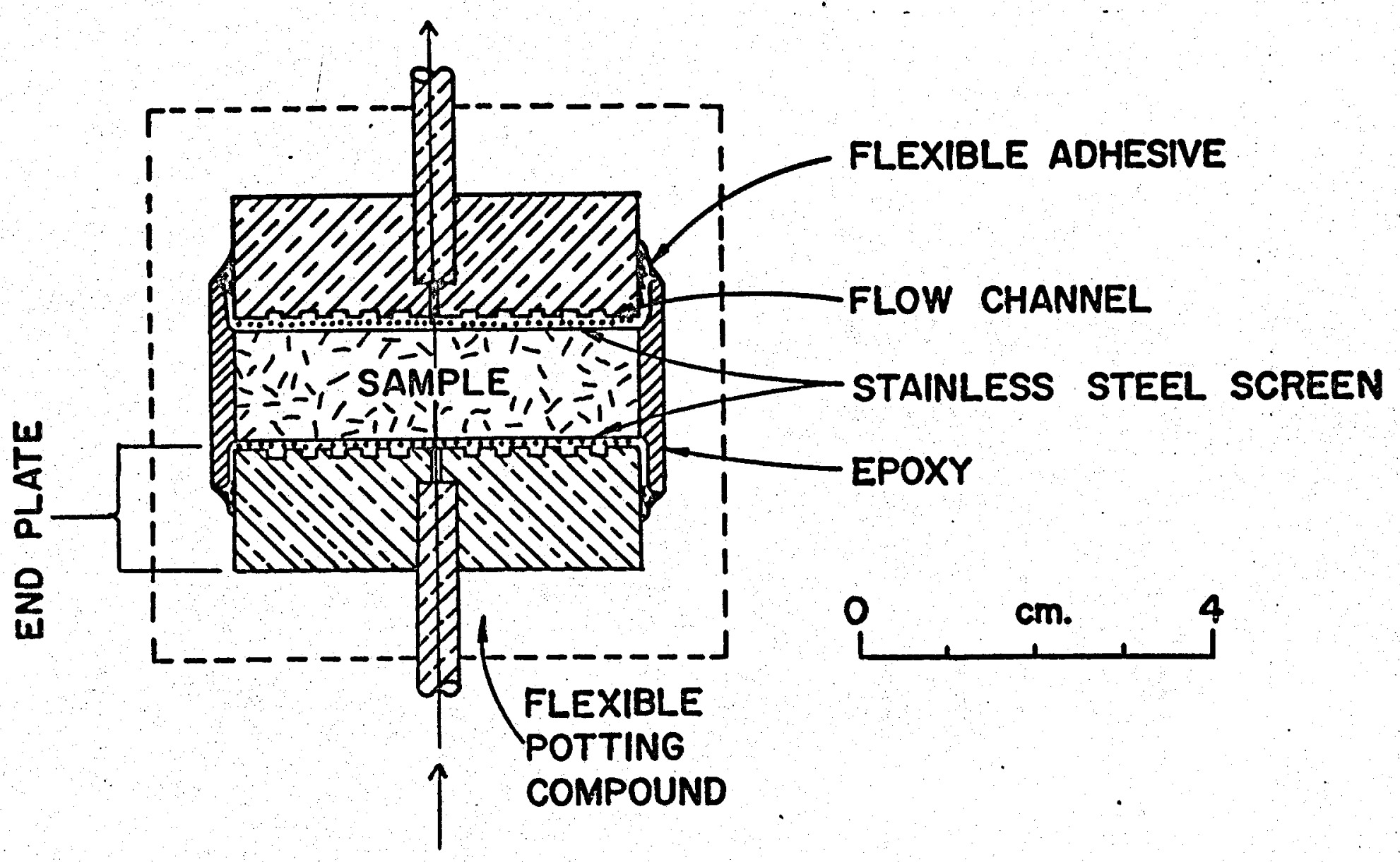

Figure 11. Permeability assembly. Fluid flows in through the bottom tube, up through the sample, and out to atmospheric pressure through the upper tube. Electrical conductivities were measured with similar assemblies that lacked input and output tubes. 


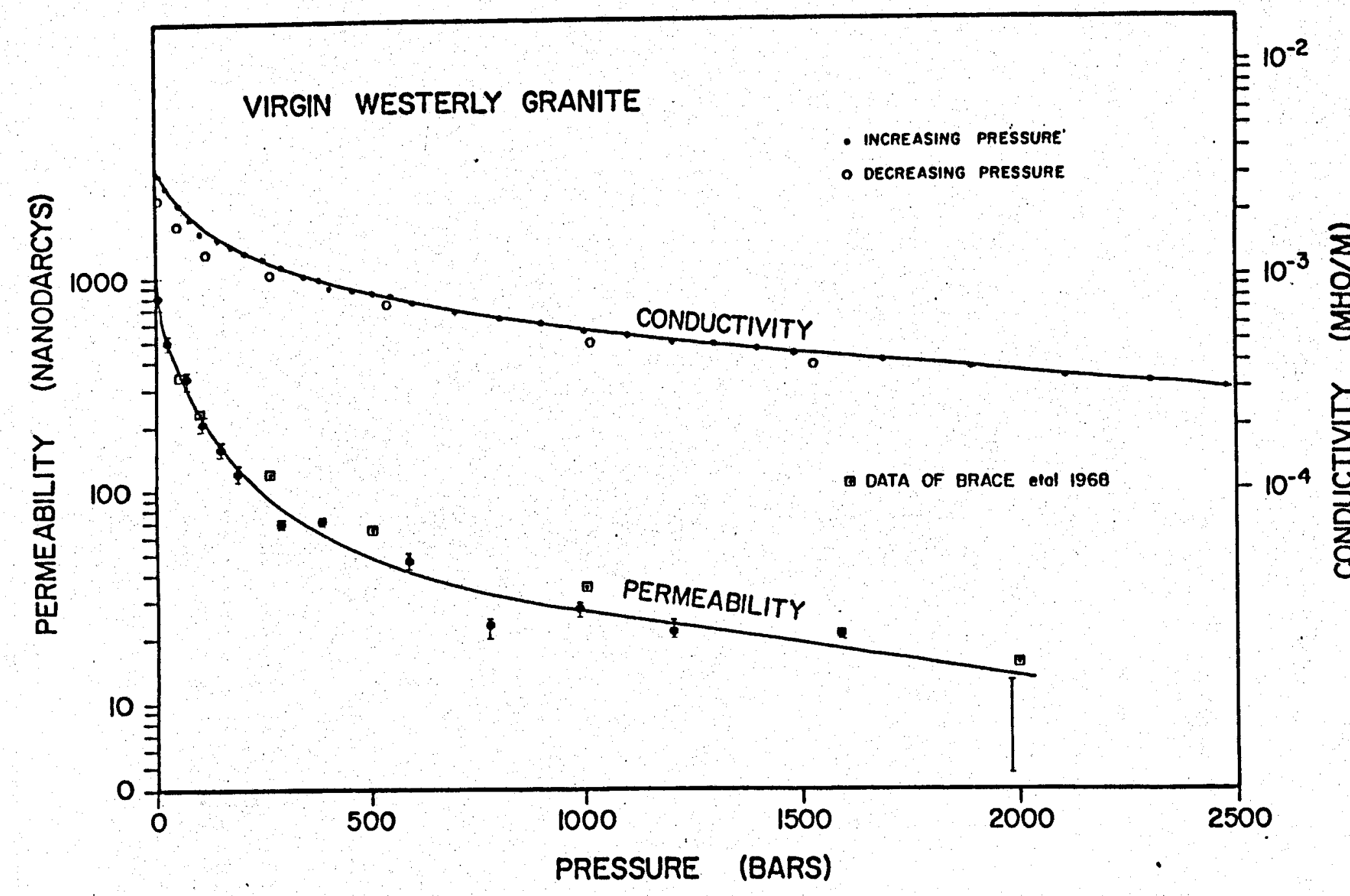

Figure 12. Permeability and conductivity versus confining pressure for virgin Westerly granite. Note: For the permeability data, the vertical bars represent the spread of measured values, the solid or open symbols are the mean values. 


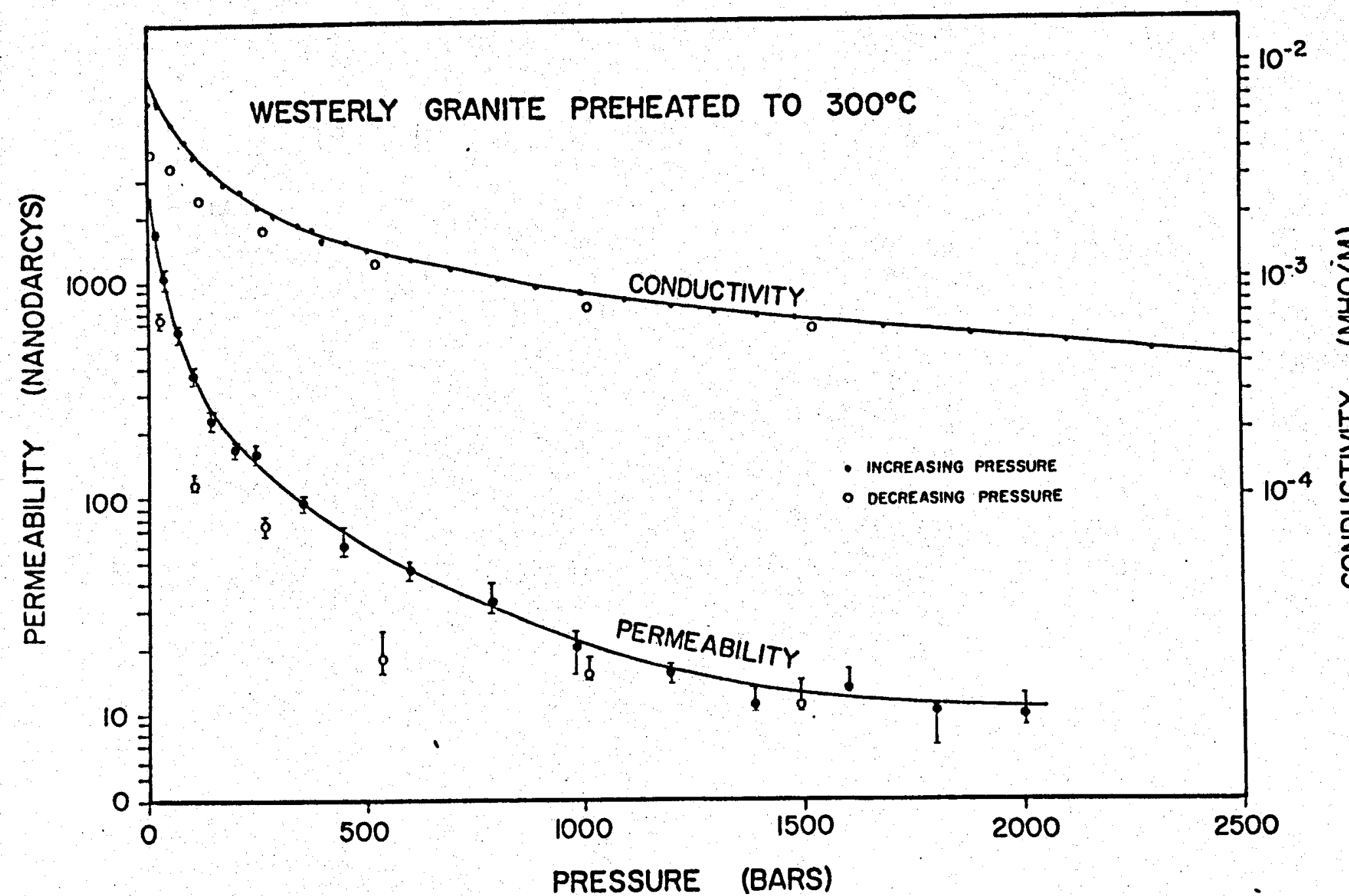

Figure 13. Permeability and conductivity versus confining pressure for westerly granite preheated to $300^{\circ} \mathrm{C}$ (see note for Figure 12). 


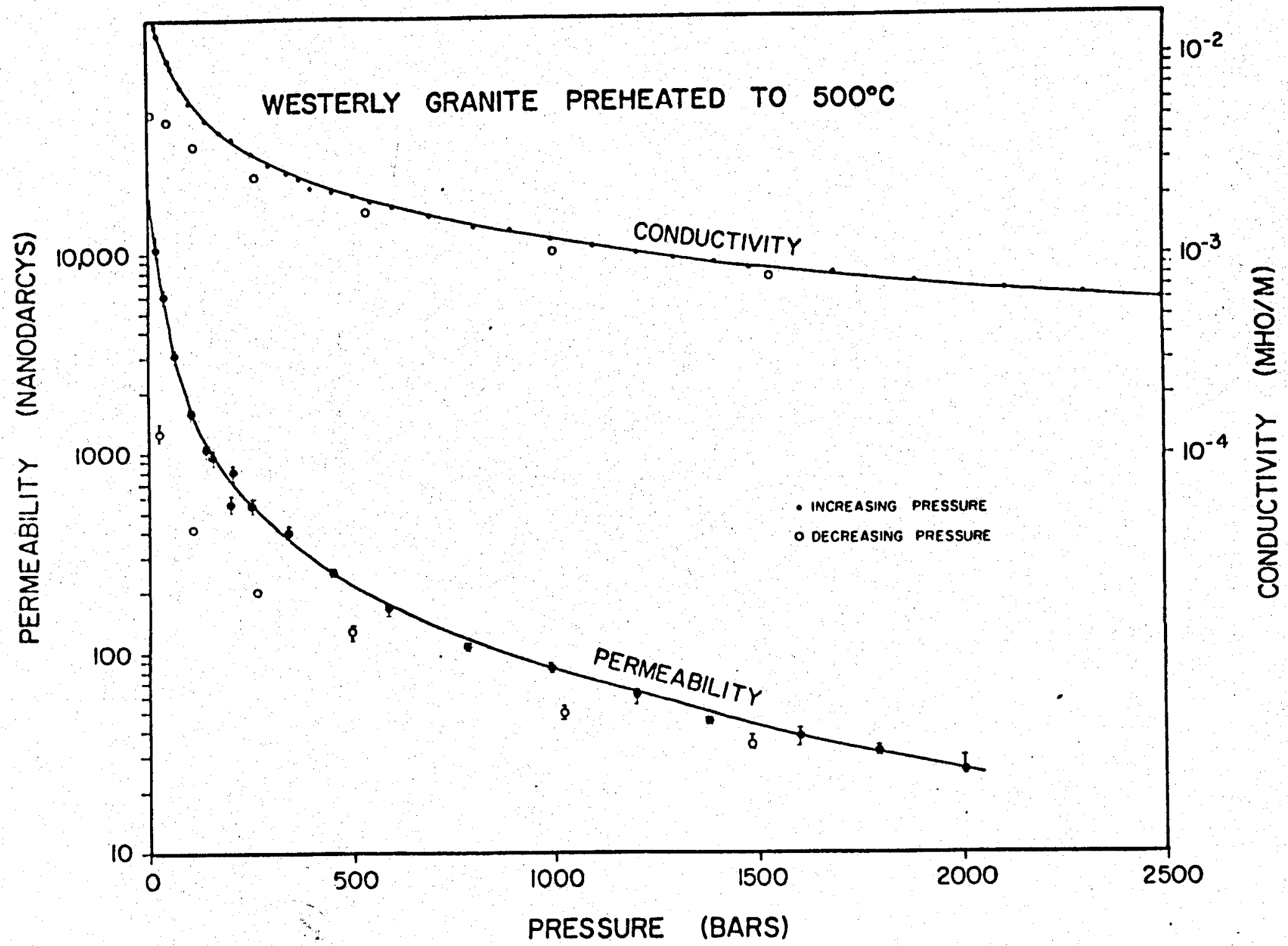

Figure 14. Permeability and conductivity versus confining pressure for Westerly granite preheated to $500^{\circ} \mathrm{C}$ (see note for Figure 12). 


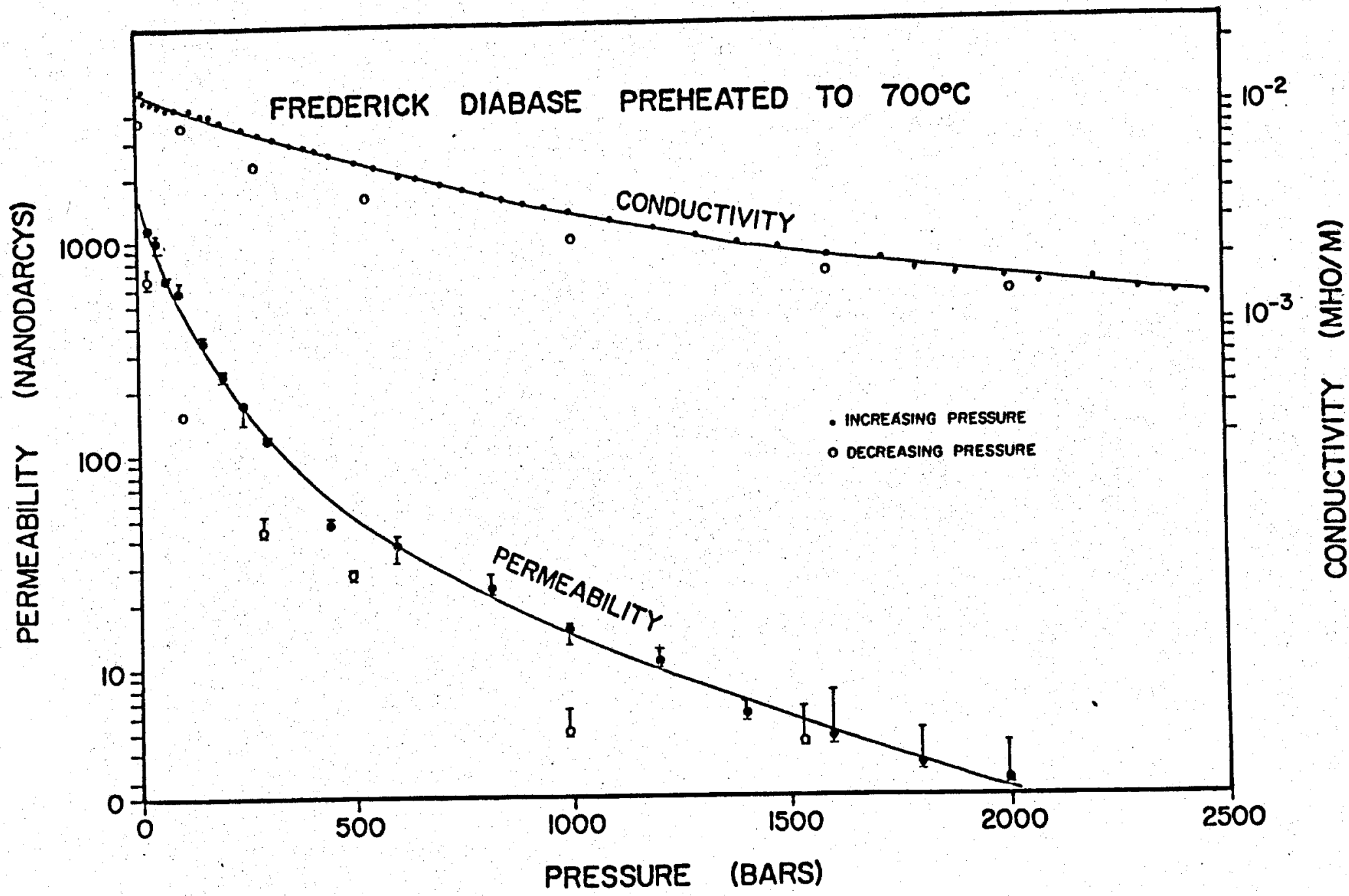

Figure 15. Permeability and conductivity versus confining pressure for Frederick diabase preheated to $700^{\circ} \mathrm{C}$ (see note for Figure 12). 
newly created in the preheated diabase. The new cracks have smooth and well-matched walls, as observed with the SEM, and close more efficiently. This closure effect has also been observed recently (Batzle et al., 1979) with similar rock samples stressed uniaxially in the scanning electron microscope. .

\section{3 .2 Models}

A parallel plate model has often been used to describe fluid and electrical transport in cracks. Permeability should depend on the width to the third power in a long narrow crack. Conductivity is dependent on the width only to the first power. This simple analogy does not apply well to virgin Westerly granite. The small relative change in conductivity versus permeability as a function of confining pressure requires that crack closure be inefficient with gaps and pockets remaining open. These cracks, in effect, close as much by length as by width. However, as more new cracks are introduced, the relative change in conductivity versus permeability is much larger and more in agreement with the parallel plate model. These new cracks with wellmatched walls close much more efficiently.

We are now in the process of developing a model to relate permeability and conductivity to other measured fracture parameters. crack porosity and crack closure pressure are measured using the differential strain analysis (DSA) technique described in Simmons et al. (1974), Siegfried and simmons (1978), and our RANN/ERDA final report. For example, the DSA plot for virgin Westerly granite is shown in Figure 16. By plotting the sum of the zero-pressure intercept of the tangents to these curves 


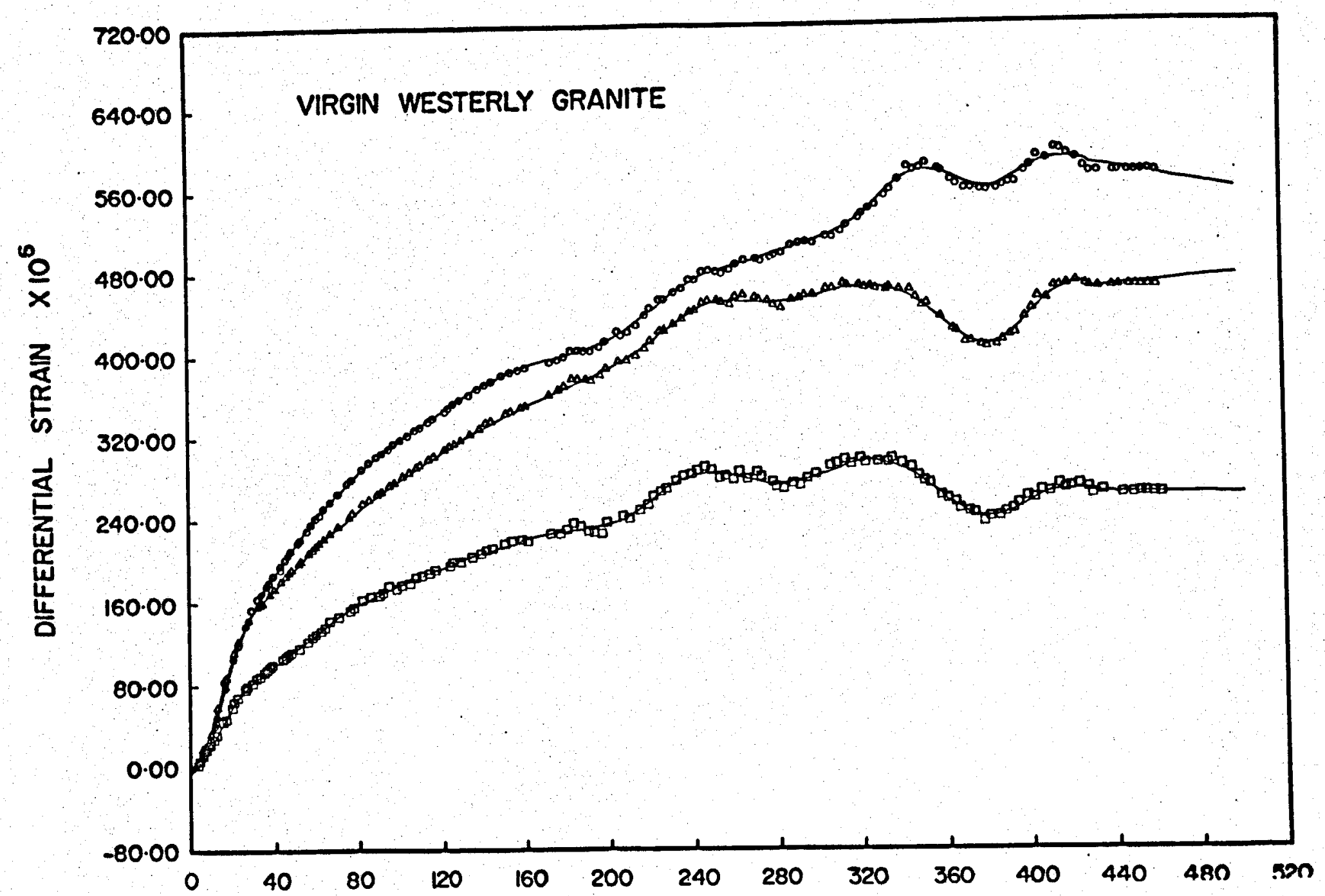

Figure 16. Differential strain in three orthogonal directions for virgin Westerly granite. Irregularities at high pressure are due to fluctuations in laboratory temperature. 
versus pressure (on a logarithmic scale), the curve of Figure 17 is produced. This curve is a measure of the decrease in crack porosity as a function of confining pressure. By using Walsh's (1965) relationship for the closure of idealized elliptical cracks, the closure pressure can be related to aspect ratio, $\alpha$ (ratio of crack width to length),

$$
\alpha=B_{C} \frac{4\left(1-v^{2}\right)}{3 \pi(1-2 v)}
$$

where $B$ and $v$ are the compressibility and Poisson's ratio, respectively, of the fracture-free matrix and $\mathrm{P}_{\mathrm{c}}$ is the crack closure pressure. The closure pressures and porosities are then grouped as indicated by the boxes in Figure 17. The resulting graph of porosity versus aspect ratio is shown in Figure 18. The same procedure has been applied to the other samples (Figure 19). The geometric mean technique (Madden, 1976) is now being used to relate these crack properties to the permeability and conductivity. With this technique, the flow properties of the rock are calculated from the geometric mean of the flow properties from all the contributing cracks. Hence, this technique is a way of calculating megascopic rock properties from the parameters used to describe single cracks. Many parameters must still be assumed, such as absolute crack width. However, other parameters can be defined which describe how the cracks interact. These last parameters include the ratio of crack width closure to length closure and the extent that the cracks of one aspect ratio are actually contained within a different aspect ratio. The results are important for determining how the irregular and 


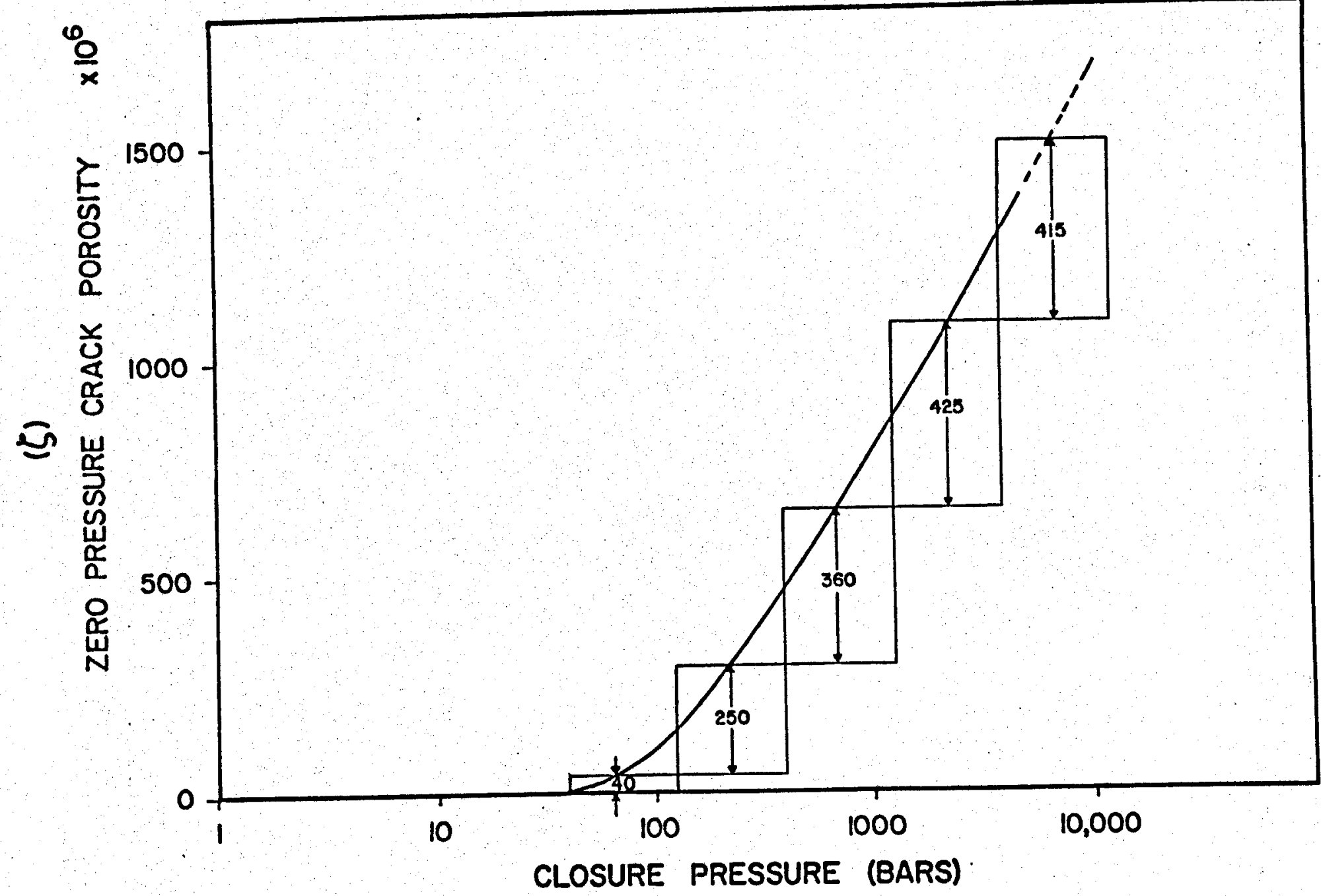

Figure 17. Crack porosity as a function of closure pressure (heave curve). The boxes and numbers within indicate the crack porosity lallocated to specific intervals of. closure pressure (see text). 


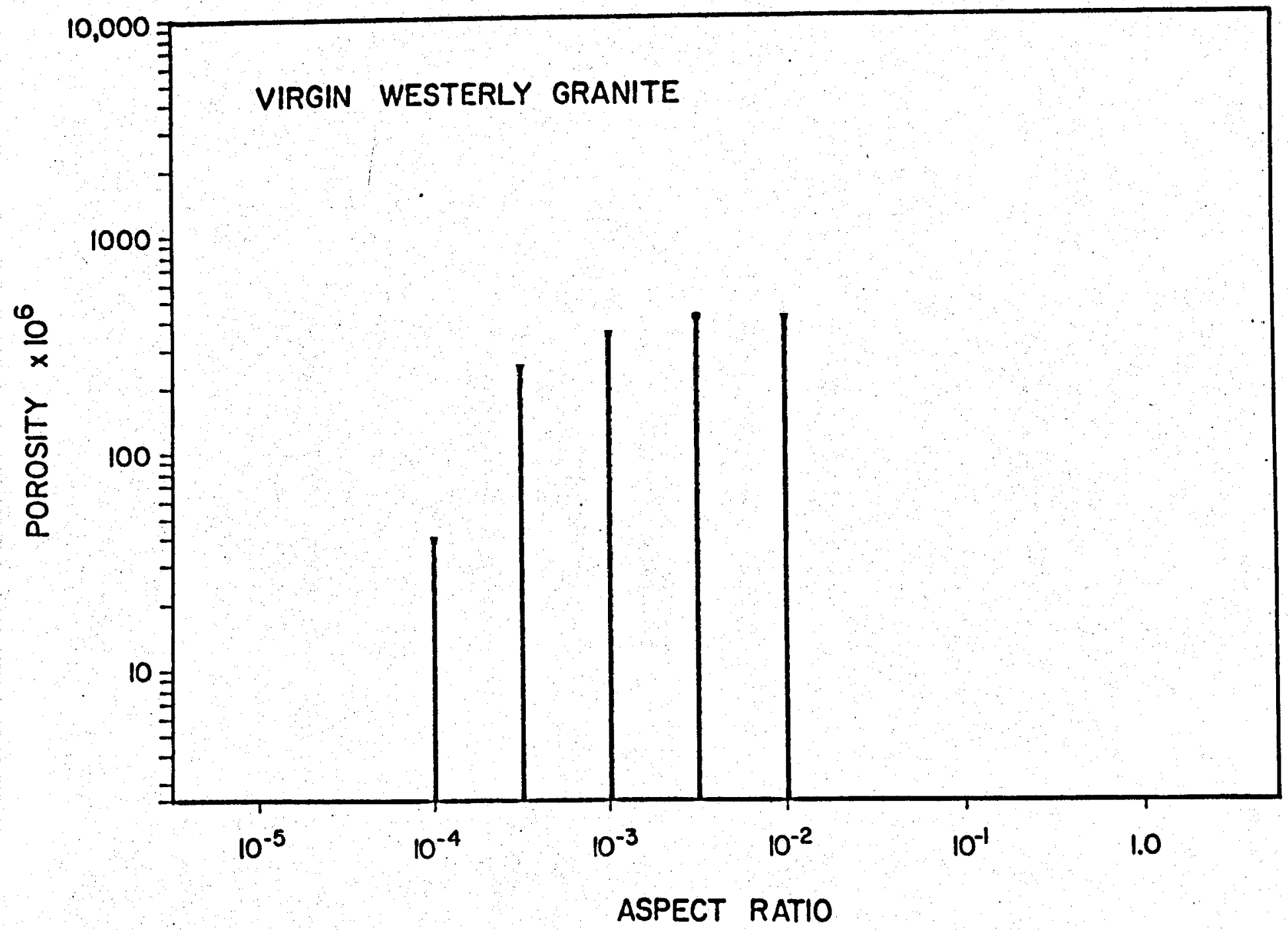

Figure 18. Crack porosity versus aspect ratio derived from the groupings in Figure 17 . (see text). 


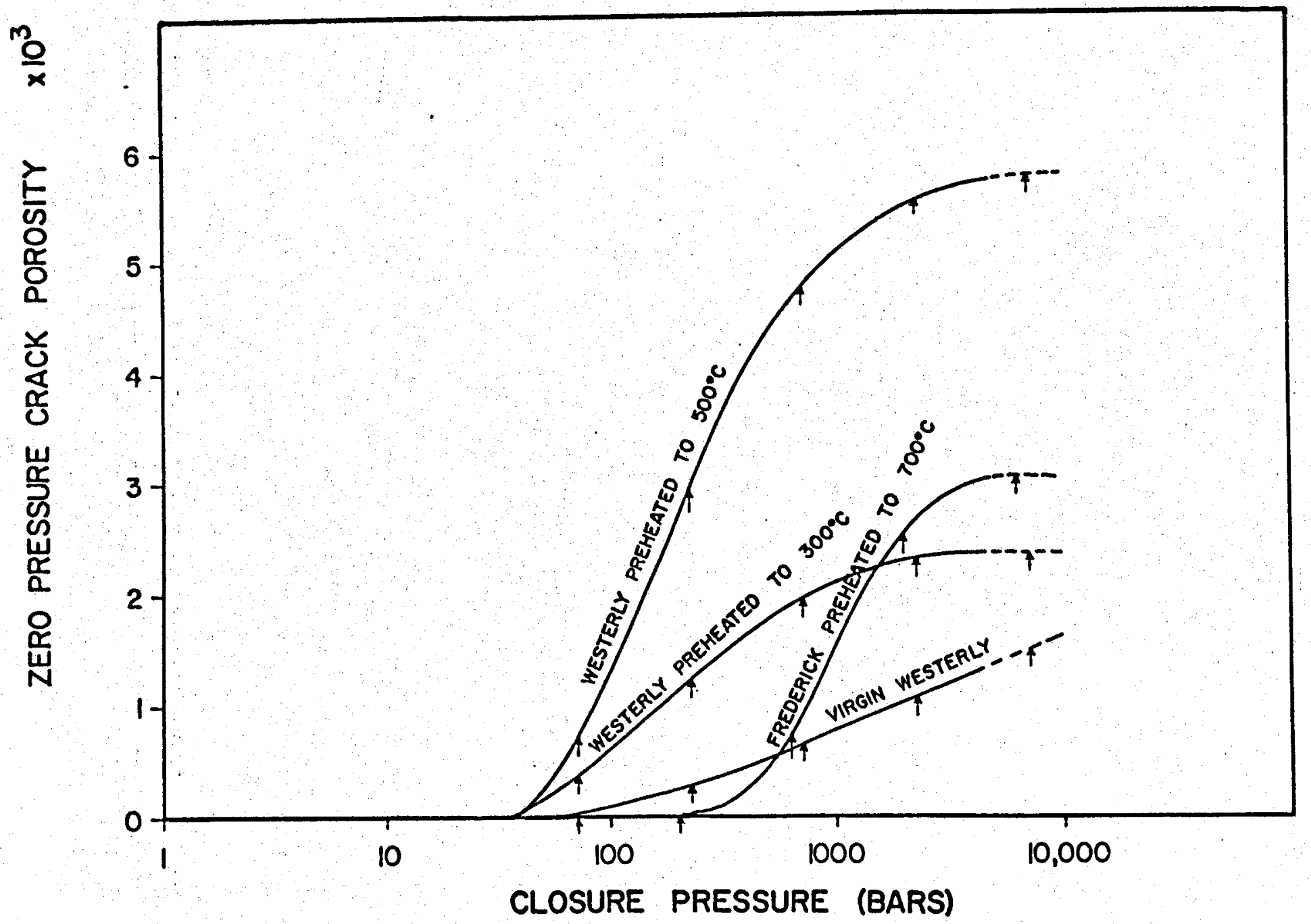

Figure 19. Crack porosity versus closure pressure for virgin Westerly granite preheated to 300 and $500^{\circ} \mathrm{C}$, and Frederick diabase preheated to $700^{\circ} \mathrm{C}$. Arrows indicate where groupings would be centered as in Figure 17. 
mismatched natural fractures behave in contrast to, and in - relationship with, the well-matched artifical fractures induced by heating.

1.3.3 A Future Application: Waste Isolation

For a radioactive waste disposal site, as an example, such models are needed to predict how permeability will vary as the rocks are heated. The situation is complicated due to the complex stress fields and numerous possible sources of fracturing. Additional cracks will be added to the original fractures due to the temperature increases and stresses related to the excavation of the site. Eventually, however, the modeling will be refined to the point where permeability contours could be drawn around the site as a function of time. The input parameters would come from heat transfer models and a relatively few samples that have been stressed, heated, and had the cracks characterized with DSA.

\subsection{Collection of Samples}

We visited the NTS in December 1978 to select samples of core for a preliminary study on waste isolation. We obtained samples from test holes UE25A\#3, UE17E, and UE25Al. The samples ranged in depth from surface to about 2500 feet and included several rock types. Crack sections, polished thin sections, and DSA blocks are being prepared.

We have obtained a suite of samples of the core from the hole arilled in the Conway granite at Red stone Quarry, near North Conway, New Hampshire, by Glenn Stewart with ERDA funds. This suite will be used to study the migration of radioactive 
elements. Specimens will be prepared for crack-examinations during the next few months. 


\subsection{REFERENCES}

Batzle, M.L., G. Simmons, and R. Siegfried, Direct observation of fracture closure in rocks under stress, (ABS), EOS, in press, 1979.

Brace, W.F., J.B. Walsh, and W.T. Frangos, Permeability of granite under high pressure, J. Geophys. Res., 73, 2225-2236, 1968.

Combs, J., Heat flow determinations and implied thermal regime of the Coso geothermal area, California, (ABS), EOS, 57. 1009, 1976.

Feves, M. and G. Simmons, Effects of stress on cracks in Westerly granite, Bul1. Seism. Soc. Am., 66, 1755-1765, 1976.

Furgerson, R.B., progress report on electrical resistivity studies, Coso geothermal area, Inyo County, California, Naval Weapons Center, China Lake, California, TP 5497, $66 \mathrm{pp}, 1973$.

Runze, J.F., L.G. Miller, and J.F. Whitbeck, Moderate temperature utilization project in the Raft River Valley, in proceedings, Second United Nations Symposium on the Development and Use of Geothermal Resources, 3, $2021=20 \overline{30}, 1976$.

Kunze, J.F. Idaho geothermal development projects annual report for 1976, Idaho National Engineering Laboratory, 38 pp.. 1977 .

Ianphere, M.A., G.B. Dalrymple, and R.I. Smith, K-Ar ages of Pleistocene rhyolitic volcanism in the Coso Mountains, California, Geology, $3,339-341,1975$.

Liou, J.G., Analcime equilibria, Lithos, 4, 389-402, 1971.

Madden, T.R., Random networks and mixing laws, Geophysics, 41 , $1104-1125,1976$.

Padovani, E.R., S.B. Shirey, and G. Simmons, characteristics of microcracks in amphibolite and granulite facies grade rocks from southeastern Pennsylvania, in preparation, 1979 a.

Padovani, E.R., M.L. Batzle, and G. Simmons, Characteristics of microcracks in samples from the drill hole Nordlingen 1973 in the Ries Crater, Germany, Proc. Iunar Sci. Conf. 9th, in press, $1979 \mathrm{~b}$.

Richter, D., G. Simmons, and R. Siegfried, Microcracks, micropores, and their petrologic interpretation for 72415 and 15418, Proc. Lunar Sci. Conf. 7th, 1901-1923, 1976. 
Richter, D. and, G. Simmons, Microcracks in crustal igneous rocks: microscopy, in The Earth's Crust: Its Nature and Physical Properties, Geophys. Monogr. Ser., vol. 20 , edited by J.G. Heacock, AGU, Washington, DC, 149-180, 1977.

Shirey, S.B., M.L. Batzle, and G. Simmons, Microfracture characteristics of geothermal systems, (ABS), Geol. Soc. Am., Abstracts with Programs, 1978.

Siegfried, R. and G. Simmons, Characterization of oriented cracks with differential strain analysis, J. Geophys. Res.? 83, 1269-1278, 1978 .

Simmons, G., R. Siegfried, and M. Feves, Differential strain analysis: a new method for examining cracks in rocks, J. Geophys. Res.. 79, 4383-4385, 1974.

Simmons, G., R. Siegfried, and D. Richter, Characteristics of microcracks in lunar samples, Proc. Lunar Sci. Conf. 6th, $3227-3254,1975$.

Simmons, G., M.L. Batzle, and S. Shirey, Final report on microcrack technology for geothermal exploration and assessment, 296 pp., 1978.

Simmons, G., Physical properties of sandstones, in Annual Report and Proposal to Schlumberger-Doll Research Center, 9-36, 1978 .

Stoker, R.C., D. Goldman, and S.J. Prestwich, Reservoir engineering, in Geothermal R\&D Project Report for Period July 1 , 1976 to September 30,1976, Idaho National Engineering Laboratory, report no. TREE-1030, 3-14, 1976.

Stoker, R.C., D. Goldman, and J.F. Kunze, Deducing production zones from well $\operatorname{logs}$, in Geothermal: State of the Art, Geothermal Resources Council, Transactions, 279-280, 1977.

Walsh, J.B., The effect of cracks on the compressibility of rocks, J. Geophys. Res. . 70, 381-389, 1965.

Williams, P.L., K.L. Pierce, D.H. McIntyre, and P.W. Schmidt, Preliminary geologic map of the southern Raft River area, Cassia County, Idaho, unpublished geologic map, U.S. Geological Survey, Denver, 1974 .

Williams, P.L., D.R. Mabey, A.A.R. Zohdy, H.Ackermann, D.B. Hoover, K.I. Pierce, and S.S. Oriel, Geology and geophysics of the southern Raft River Valley geothermal area, Idaho, USA, in Proceedings, Second United Nations Symposium on the Development and Use of Geothermal Resources, $2,1273-$ $\overline{1282}, 1976$. 